\title{
New insights into application of nanoparticles in the diagnosis and screening of novel coronavirus (SARS-CoV-2)
}

\author{
Abhimanyu Tharayil ${ }^{1}$ (D) R. Rajakumari ${ }^{2} \cdot$ Amresh Kumar $^{3} \cdot$ Manabendra Dutta Choudhary $^{3} \cdot$ Parth Palit $^{4}$. \\ Sabu Thomas ${ }^{1,5}$
}

Received: 7 January 2021 / Accepted: 3 February 2021 / Published online: 31 March 2021

(C) Qatar University and Springer Nature Switzerland AG 2021

\begin{abstract}
Novel coronavirus disease 2019 (COVID-19) is by far the worst pandemic disease in the current millennium. The first human-tohuman transmission was observed in December 2019 in China and is caused by the highly contagious severe acute respiratory syndrome coronavirus 2 (SARS-CoV-2), which has infected millions of people within months across the globe. SARS-CoV-2 is a spike protein enveloped virus with particle-like characteristics and a diameter of 60-140 nm. Real-time PCR, reverse transcriptase PCR, isothermal PCR, immunological-based detection technique and nano-based diagnostic system have been explained for the identification and differentiation of different types of virus including SARS-COV-2. Synthetic nanoparticles can closely mimic the virus and interact strongly with its virulent proteins due to their morphological similarities. Some of the antiviral nanomaterials are also discussed, for example zinc oxide nanoparticle is an antiviral agent with a tetrapod morphology that mimics the cell surface by interacting with the viral capsid. It suppressed the viral proteins upon UV radiation due to reaction caused by photocatalysis. Hence, nanoparticle-based strategies for tackling viruses have immense potential. The second part of the review points to the latest in vitro and in vivo procedures for screening viral particles and the usage of nanoparticles in diagnostic and therapeutics. This would be beneficial for early detection and assists for the safe and effective therapeutic management of COVID-19.
\end{abstract}

Keywords COVID-19 $\cdot$ Biosensor $\cdot$ Nanotechnology $\cdot$ In vitro assay $\cdot$ COVID-19 testing

\section{Introduction}

Nanotechnology is a relatively new field of science that has attracted attention of researchers because of its immense potential in various applications ranging from energy production

Abhimanyu Tharayil and R. Rajakumari contributed equally to this work.

Sabu Thomas

sabuthomas@mgu.ac.in

1 School of Energy Materials, Mahatma Gandhi University, Kerala 686560, India

2 International and Inter-University Centre for Nanoscience and Nanotechnology, Mahatma Gandhi University, Kerala 686560, India

3 Department of Life Sciences and Bioinformatics, Assam University, Silchar, India

4 Department of Pharmaceutical Sciences, Assam University, Silchar, India

5 School of Chemical Sciences, Mahatma Gandhi University, Kerala 686560, India to biomedical applications. Nanotechnology-based system is useful in surgery, cancer diagnosis and therapy along with identification of molecular disease markers, implant technology, devices for drug delivery etc. [1-3]. The superiority of nanomaterial is due to their unique size-dependent properties and has become indispensable in many areas of human activity. The ongoing COVID-19 pandemic can only be handled with multidimensional scientific approaches. The first and basic requirement is the diagnosis and detection of the causative virion particles. It is also very important to develop fast and cost-effective testing methods that enable us to identify and isolate infected people, thereby containing the spread of the virus. A large-scale speedy tracking-testing-therapy (t-t-t) is required for SARS-CoV-2 as many of the patients are asymptomatic in nature. Since a large population needs to be tested, the testing methods need to be precise and patient compliant, which have the ability to be scaled up and most importantly cheap. Various types of testing method are available based on the nucleic acid, antigen, antibody, nanotechnology and biochemical technique. Variation in PCR is used for the detection 
of DNA in sample. Real-time PCR, a rapid and sensitive technique uses SYBR-Green or other probes to detect the presence of viral DNA or RNA [4]. Antigen and antibody-based immunoassay is also used for detection of presence of viral capsid protein in infected sample. ELISA is one of the examples which can detect SARS-CoV-2 spike protein or antibody with high specificity and sensitivity [5, 6]. Antiviral medicinal therapeutics are very essential to reduce the spreading and mortality caused by the virus particles [7]. The in vitro and in vivo bioassay may be carried out for diagnosis and development of therapeutic agent against SARS-COV-2. The in vitro method was developed to evaluate the SARS-CoV-2 inhibitors by application of DEP (Dual Envelope Pseudovirion) technique. This process includes the coating the protein envelope by the luciferase enzyme and the second one encodes the control from the target virus [8]. The in vitro analysis of carbonbased nanomaterial on the inhibition of virus was also well explained. The mode of action depends on how it interacts with the host cells and the way the nanoparticles are injected at different time intervals, so that it could prevent the virus from damaging the host cells. For example, the study on the glycofullerenes demonstrated to be very effective in the current ongoing pandemic virus SARS-CoV-2 which involves the click chemistry strategy to anchor the ligands to inhibit the virus [9]. Therefore, the aim of this review article is to focus on the various methods of diagnosis, therapeutic and in vitro and in vivo screening technique against SARSCOV-2 for control and manage the COVID-19 pandemic across the globe.

\section{Nanoparticle and diagnosis of SARS-CoV-2}

Diagnosis of SARS-CoV-2 is an important step that depends on the understanding of virus structural protein and genetic components. The replication of SARS-CoV-2 virus starts upon the entry through the specific binding with ACE2 protein on host cells $[10,11]$. The current technique for detection of SARS-CoV-2 is based on the presence of C-reactive protein and serological components. CRP identifies the presence of virus particle by reacting with piece of genetic code of SARSCoV-2 whereas the serological method is dependent on the extent of immunological reaction against the virus [12]. In serological methods, the presence of igG and igM is recognized in blood sample but the production of antibody occurs after 7 days of commencement of symptom [13]. However, the CRP confirms the presence of genetic material of virus in the body approximately until the day when symptom appears [14].

Today, diverse techniques are employed as highly sensitive diagnostic system for identification of SARS-CoV-2 and many new methods need to be investigated. In this regard, US researchers designed a rapid test using gold nanoparticles and termed it as efficient and fast approaches for the diagnosis of COVID-19, thereby maximizing the sensitivity and reliability of the tests $[15,16]$. The idea of the authors behind it is to attach a specific molecule to the gold nanoparticles that detect a particular protein from the genetic sequence of the SARSCoV-2 virus [16]. This interaction initiated when the biosensor binds to the virus' gene sequence, and the gold nanoparticles are responsible for the transition of the liquid reagent from purple to blue. This way the visual change indicated direct diagnosis of the SARS-CoV-2 virus in the sample. They allow the coupling of biological molecules forming hybrid structures biological Au nanoparticle, promoting a target detection of the virus. Bio-Au nanoparticle-based diagnostic system shows increased level of the sensitivity of the test and a better detection range which reduces the detection time [17]. Researchers have also used gold nanoparticles for the development of a rapid detection kit for IgG and IgM antibodies against SARS-CoV-2, which helps in minimizing the diagnostic time and the results can be displayed in less than $10 \mathrm{~min}$ [18]. Some of the problem associated with the present diagnostic system can be minimized by increasing the sample life. Samples collected from the patients need to be tested immediately to save the degradation of components such as RNA and protein because of the lack of availability of refrigerated transportation. In this regard, researchers have done amazing work to develop a sample collection kit containing an RNA stabilization fluid using nanotechnology. The kit protects viral RNA to remain stable at room temperature for up to a week, helping its safe transportation from one place to other place as per requirement. Two-dimensional nanoparticles coupled with functional DNA receptor are utilized to develop biosensor for diagnosis of SARS-CoV-2 [19]. Zhu et al. developed a diagnostic technique based on nanoparticle that used isothermal amplification mediated by multiplex transcription loop. Their results based on analysis of 33 oropharyngeal samples of patients with COVID-19 demonstrated $100 \%$ of sensitivity and $100 \%$ specificity up on analysis of 96 samples collected from non-COVID-19 patients [20].

The different modification of PCR can also be used to fulfil the requirement of highly sensitive and specific detection system of enteric virus. The reverse transcriptase PCR in integration with cell culture technique can be used to detect the slow growing or either unable to display cytoplasmic effects [21]. Propidium monoazide (PMA) is also used to differentiate the enteric virus with non-infectious virus along with RT-PCR [22]. The logic behind using the PMA is that it penetrates the damaged capsid wall of non-infectious virus; thereafter, it covalently binds to RNA on exposure to visible light. The covalently conjugated RNA became unavailable to RT-PCR for amplification. Sequence-independent single-primer amplification (SISPA), a variation in PCR technique, can be applied for diagnosis of new strain or highly diverse type of virus of unknown sequence [23]. Here, an adaptor/linker of known 
sequences can be designed and ligated to both the end of known sequences followed by amplification with a primer of known sequences. This technique is already successfully done for the detection of Norovirus concerned with gastroenteritis [24]. The real-time PCR is one of the excellent and rapid tools for the sensitive detection and quantification of virus in the sample where amplification product florescence is due to deposition of SYBR green dye or various probes [25]. The multiplex Luminex Assay show better results with high sensitivity than the conventional RT-PCR used [26]. This PCR has been successfully applied for the diagnosis of many enteric viruses simultaneously [27]. The major drawback associated with the use of this PCR is inter-laboratory variation in the plotting of standard curve along with the use of standard materials. Therefore, the application of PCR is one of the easy tools, which are applied for the diagnosis of SARS-CoV-2 virus and may be developed for detection of new variant of the same.

\section{Nanoparticle as therapeutic agent against COVID-19}

One of the immediate challenges is to discover the safe and effective therapeutic agent against novel coronavirus SARS$\mathrm{CoV}-2$. The best approach to introduce rapid therapy is to test available drugs on the market because these have reported safety and security profile as studied previously. Nevertheless, the pathophysiological properties of COVID19 should be taken into consideration while using the previously known drug that possesses established anti-microbial property as per FDA approval. For example, hydroxychloroquine and chloroquine were initially used as anti-parasitic agent, but we must be cautioned about the development of cardiotoxicity in patients with COVID-19 during consumption [28]. Ivermectin has been used successfully for controlling viral load to contain the replication of the virus [29]. Several applications of antiviral drugs have been used by repurposing to treat the COVID-19 such as Ribavirin, Remdesivir, and Favipiravir but show tremendous adverse reactions. In order to handle this loophole, we may use nanocarrier coupled with receptor ligand-based drug delivery for effective management of viral pandemic [30].

According to the literature, nanotechnology provides advantages over present system of diagnosis such as liposomes, polymeric and lipid nanoparticles, metallic nanoparticles, and micelles. The merits of the use of nanoparticle include the proper encapsulation of drugs, slow release of drugs, and assisting in the improvement of properties of drug molecules [31].

Researchers from Cyprus have done great work on chitosan nanoparticles for aerosol application, which allow drugs to target on the epithelial tissues of lungs and ensuring the controlled release and minimizing the toxicity level [32]. In this regard, the authors' statement is very important as chitosan nanoparticles, called Novochizol, permit the encapsulation of several drugs to transport them to the lungs in order to have effective action to cure severe COVID-19 infections. According to the developers of this product, Novochizol aerosols can provide a therapeutic dose to a patient for a period ranging from $25 \mathrm{~min}$ to $3 \mathrm{~h}$. Using chitosan as nanoparticle provides a lot of benefits such as low toxicity and biodegradability in both in vitro and in vivo model. Furthermore, research on chitosan shows very good applicability in drug transport to lungs [33]. Therefore, chitosan nanoparticle may be the potential alternative to use it in transport of drug against SARS-CoV-2. Furthermore, chitosan has very good mucoadhesive properties which helps in the reduction of intestinal reaction caused due to COVID-19 infection [34]. Research on the COVID-19 patient has also confirmed that the SARS-CoV-2 virus changes the gastrointestinal microbiome even after the patient recovered from SARSCoV-2. The presence of microorganism such as Coprobacillus, Clostridium ramosum, and Clostridium hathewayi in intestine may be a big concern with the severity of COVID-19 [35]. This could happen due to the dysbiosis of the microorganism in the gastrointestinal tract. Therefore, we can say that chitosan nanoparticle could be helpful in the control, transportation and release of drugs and shows good benefits to patients at pulmonary and intestinal level. An important nanoparticle such as nano sponges from pulmonary type II epithelial cells or human macrophages has been developed. This nano sponges are very good attractant of SARS-CoV-2 virus and can be neutralized after being captured. Therefore, it could be helpful in the development of preventive measures of SARS-CoV-2 [36].

COVID-19 patients may suffer from organ failure due to cytokine storm. Cytokine storm is COVID-19-associated serious complication, which consists of hyper production of proinflammatory cytokine [37].

The chemokine receptor CCR2 may be inhibited by encapsulating the small interfering RNA (siRNA) in lipid nanoparticle. The sufficient degradation of CCR2 mRNA in monocytes checks the deposition of cytokine at inflammatory sites. Through this process, the body immune system controls the recruitment of unwanted monocytes during the inflammatory process and demonstrated the effective results in mouse model [38]. As previously known, some of the commercial marketed medicines such as tocilizumab and $\mathrm{c} 1$ esterase inhibitors have shown the very effective outcome in the management of cytokine storm [39]. Further study by Dormont et al. on the conjugation of nanoparticles with squalene with the antiinflammatory drug adenosine and alpha-tocopherol have been used at the targeted region for acute inflammation [40]. The mice with acute inflammatory state and cytokine storm were treated with application of squalene nanoparticle and show the 
reduction in level in proinflammatory cytokine along with increasing the concentration of IL10 to control the inflammatory response. The efficiency of nanoparticle can also be enhanced by modifying the different functional groups on the surface and to bond with specific receptor. This approach may be applied for blocking the contact of the virus with target cell. The work of Loczechine et al. on the carbon quantum dots (CQDs) that were combined with boric acid showed the inhibitory effect on the human coronavirus HCoV-229E. This study demonstrated the interaction of functional group (boronic acid) of the CQDs with the receptors of the virus and glycoprotein spike protein $(\mathrm{S})$, leading to the binding inhibition of virus with cell [41]. Thus, this kind of approach could be effective in controlling the spread of SARS-CoV-2 at various stages of infection.

\section{Application of nanomaterials in the development of biosensors for SARS-CoV-2}

Nanomaterial incorporated biosensor is one of the options for development of rapid sensitive and is considered a low-cost method for the identification and diagnosis of virus of viral diseases as per previous record. Nano-based biosensor may provide easy, rapid and sensitive detection of SARS-CoV 2, which supports the better control, diagnosing and treatment of COVID-19 [42]. The mechanism of biosensor for the detection of SARS-CoV-2 carries three important aspects, including the target for identification (e.g. viral RNA and proteins, or human immunoglobulins), identification methods (based on aptamers, antibodies, nucleic acid probes, receptors), and the amplification of signals and transduction systems (based on electrical, surface plasmon resonance, electrochemical, optical, mechanical systems, and fluorescent signals) [43-45].

The SARS-CoV-2 can be detected by the application of field effect transistor (FET)-based biosensing gadgets and its performance is evaluated by using the cultured virus, protein antigen and nasopharyangeal swab sample taken from COVID-19 patients. This biosensor is designed with graphene sheet FET coated with antibody against SARS-CoV-2 spike protein. The decorated FET sensor can detect SARS-CoV-2 spike protein at the concentration $1 \mathrm{fg} / \mathrm{ml}$ in phosphatebuffered saline, and $100 \mathrm{fg} / \mathrm{ml}$ in medical transfer vehicle. This FET-based biosensor also demonstrated good sensitivity for the identification of SARS-CoV-2 with no pretreatment required [46]. The important aspect associated with the sensor device is that it does not show any cross-reactivity with MER$\mathrm{CoV}$, demonstrating significant potential in detection of SARS-CoV-2 spike antigen in sample.

The nanoparticle containing magnetic characters coupled with specific receptor of virus can also be employed for the detection of COVID-19. The device uses viral genome ssRNA and SARS-CoV-2 spike protein was designed with the help of magnetic nanoparticles. The detection of SARS$\mathrm{CoV}-2$ can be done with the help of giant magnetoresistive biosensor (GMR) along with magnetic nanoparticles, revealing the good sensitive and potential biosensing [47].

Further study was conducted on gold NPs that were used for the construction of electrochemical biosensor in order to detect SARS-CoV-2 spike S1 protein antigen. They had designed the substrate of biosensor with a fluorine-doped tin oxide, while gold NPs were applied as a signal amplifier owing to the significant electrical conductivity [48]. For the preparation of efficient biosensing method, the monoclonal antibodies developed against SARS-CoV-2 were immobilized to prepare the immunosensor. The limit of detection (LOD) of the immunosensor was about $10 \mathrm{fM}$ for detection of the COVID-19 antigen (spike protein). In addition, a very cheap and sensitive electro sensor was designed based on cobalt-coupled $\mathrm{TiO}_{2}$ nanotubes for the detection of SARS-CoV-2 spike located on the surface of the virus within about $30 \mathrm{~s}$ [49]. This immunosensor could recognize the S-receptor binding protein of SARS-CoV-2 at very low concentration ranging from 14 to $1400 \mathrm{nM}$. Further, the limits of detection of virus particle can be enhanced by using the modern gene editing CRISPERcas during the viral diagnosis [50]. This gene editing technique was previously modified to biological sensor using CRISPER-Chip coupled with graphene-based field effect transistor (FET) that is capable of detection of $1.7 \mathrm{fM}$ concentration of nucleic acid within 15 min without using any amplification system [51]. Currently, this technique has been applied for the detection of SARS-COV-2 in less than $40 \mathrm{~min}$. The surface plasmon resonance and localized surface plasmon resonance (LSPR)-based biosensor is previously studied in relation to detection of nucleic acid and viral infection [52]. Recently, nucleocapsid-based antibody was diagnosed by use of SPR-based biosensor, which is SARS-COV-2 specific in undiluted human serum [53]. SPR-based biosensor conjugated with peptide and SARS-CoV-2 nucleoprotein recombinant protein detected anti-SARS-COV-2 antibody in nanometre range of concentration.

An innovative idea for rapid and sensitive detection of the SARS-CoV-2 spike-1 (S1) protein has been introduced that is the use of the SARS-CoV-2 receptor ACE-2 protein matched pairs with commercially available antibodies [54]. ACE-2 and monoclonal antibody against $\mathrm{S} 1$ protein $(\mathrm{S} 1-\mathrm{mAb})$ were paired with each other for detection in a lateral flow immunoassay (LFIA). The system did not show cross-reactivity with the SARS-CoV Spike-1 or MERS-CoV Spike 1 protein. Subsequently, the SARS-CoV-2 S1 protein was recognized in the ACE2-based LFIA system. The limit of detection 
(LOD) was found to be about $1.86 \times 10^{5}$ copies $/ \mathrm{mL}$ in clinical specimens from COVID-19 patients without any crossreactivity for nasal swabs [54]. Owing to all these, it can be said that the biosensors designed based on the nanotechnology are rapid/easy to use, specific in nature without cross reaction. The SPR-based biosensor is rapid and highly sensitive and detects the sample within $15 \mathrm{~min}$.

\subsection{In vitro assay procedures for screening and evaluation of viral entry inhibitors}

There are different types of assays which include cell-cell fusion assays, cell-virus fusion assays, and in vitro biochemical assays that were developed for screening the inhibitors of viral entry (Fig. 1). The entry in the case of enveloped viruses will be formed by the fusion of the envelope in the cellular membrane. This process is mediated by the glycoprotein which consists of transmembrane gp41 and binds to the cell receptors like CD4, CXCR4 or CCR5 by activating the refolding the glycoprotein [56]. The refolding encompasses the $\mathrm{N}$ and $\mathrm{C}$ terminal domains of the glycoprotein by forming helical bundle. Another in vitro assay method was developed for evaluating the SARS-CoV inhibitors by DEP (Dual Envelope Pseudovirion) method. In this process, it encodes the protein envelope by the luciferase enzyme and the second one encodes the control from the target virus. By the Dual-Glo Luciferase assay, this reduces the false positive results and it is used to screen the molecules, which prevents the entry of viruses. By this screening method, it can identify multiple compounds having inhibitory activity against different kinds of viruses [57, 58].

\subsection{In vitro assay procedures for screening viral capsid inhibitors}

Most of the viruses enter the host cells through endocytosis mechanism. There are mainly two methods that are involved for screening the viral capsid and they are utilization of virus specific restriction factors and ultracentrifugation [59]. The ultracentrifugation process (in vitro core stability assay) is the one in which it dissolves the viral membrane and turns into a gradient layer of sucrose where the core of viral particles is concentrated [60]. In this assay, this involves the cellular factors to wash out the infection by the antiviral components by binding to the capsid core. The virions were separated by the centrifugation by the velocity gradient mechanism in which it binds to the capsid core by dissolving the membrane to release the viral core. It depends on the processes such as $\mathrm{pH}$ lowering, changing the ionic strength and adding uncoating factors which affect the viral core [61].

\subsection{In vitro assay procedures for screening and evaluation of replication inhibitors}

The enzymes such as polymerase, methyl transferase, helicase, kinase and integrase play a major role in inhibiting the replication of viruses. The inhibitors of polymerase enzyme represent many clinically approved antiviral moieties which also inhibits the protease, integrase
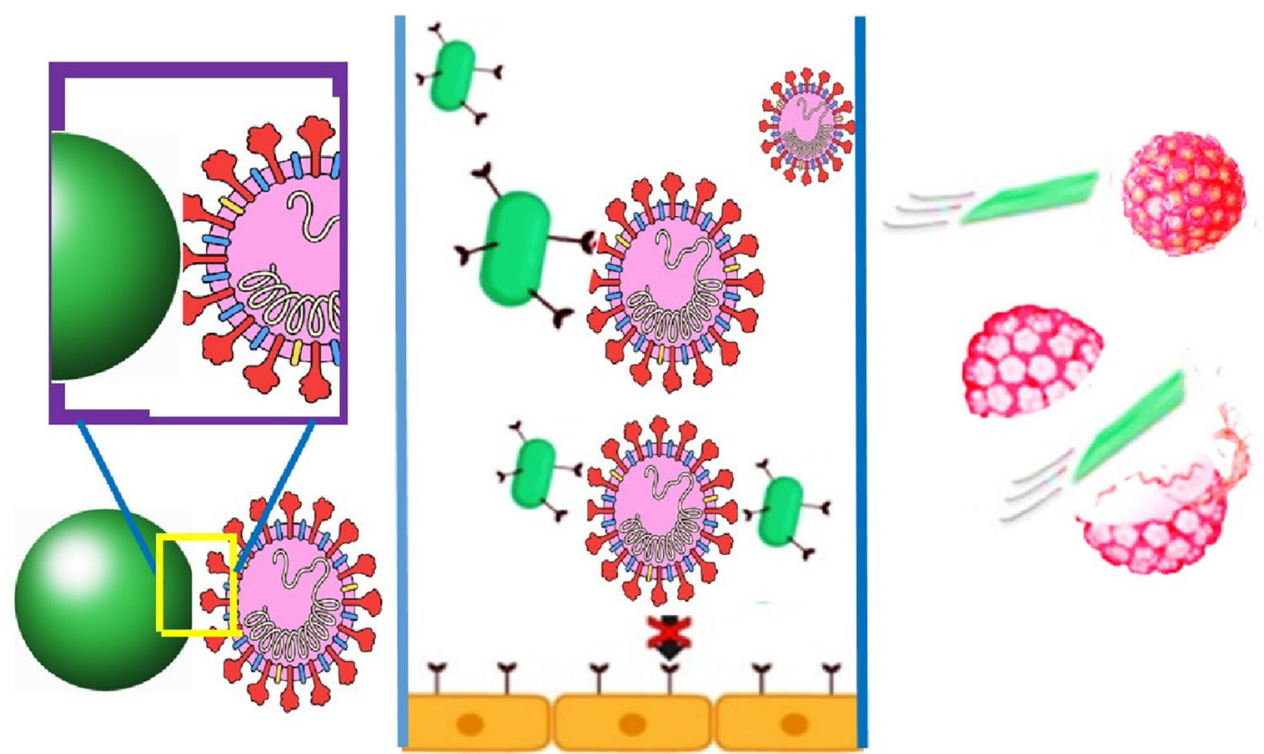

\section{Capsid Denaturation Mimicking Cell Surface}

Mechanical Breaking

Fig. 1 Illustration of the main mechanisms of blocking virus entry into host cells: capsid denaturation, mimicking cell surface, and mechanical breaking of the virus [55] 
and immunostimulatory. Usually, polymerase was considered to be the desired target for the various inhibitors. They inhibit the nucleotide, pyrophosphate and nonnucleoside analogues by inhibiting the replication of viruses. The plaque assay method which is a non-specific assay method is used for analysing the effectiveness of the polymerase inhibitor and also it prevents the cytopathic activity of the virus $[62,63]$. Then, the methyl transferase enzyme involves the methylation process in which the viral gRNA mimics the cellular mRNA cap to improve the probability of escaping the virus from the cellular defence mechanism. This methyl transferase is a very efficient therapeutic agent and in which the $\mathrm{C}$ terminal part of the SARS nsp14 protein exhibits N7-methyltransferase activity forming the gRNA cap. This $\mathrm{N}$ terminus improves the prevention of viral replication by inducing antiviral signalling pathways $[64,65]$. Helicase is the other enzyme which helps in inhibiting the viral replication and it is used in the fluorescence assays to find the inhibitors targeting the SARS-CoV helicase (nsp 13). This method is also used for the analysis of RNA helicase activity of the virus. Recently, a colorimetric assay is used to determine the helicase activity using DNA-conjugated gold nanoparticles. It is based on the optical properties of the Au nanoparticles in which it induces DNA unwinding to enhance the inhibitor activity. Another assay involves in the inhibition of replication is fluorescence method, in which the helicase analyses the unwinding of DNA. An example is the graphene oxide-based fluorescence monitoring of viral helicase activity. Here, it measures the changes in the luminescent property of the transition metals along with the DNA during the helicase mediated inhibition [66, 67]. The fourth important enzyme for the inhibition of viral replication is tyrosine kinases and serine/threonine kinases in which they induce fluorescence emission. The assay methods involving kinase enzymes are fluorescence polarization, immunochemical, Western blotting, ELISA, or immune precipitation methods. In the fluorescence polarization, the SARS$\mathrm{CoV}$ kinase inhibitors are based on the preventing the replication by phosphorylation reaction. Here, they use the specific antibodies like phosphorylated serine/ phosphorylated threonine in which they detect the protein/peptides. Furthermore, the mass spectrometry-based analysis proves that the kinase inhibitors depend on litigation method which used against the protein target to prevent the replication of virus $[68,69]$. The integrase enzyme involves two methods to assess the screening and evaluation of replication inhibitors. The first one is radiolabeled DNA which contains cis-sequence of viral DNA wherein it targets the DNA strand to inhibit the replication. Another method involves less timeconsuming non-radioactive method for the fluorescence anisotropy measurement of DNA. This process analyses the binding of integrase enzyme to the viral DNA and it inhibits the replication when it inhibits the binding of integrase enzyme to the DNA [70, 71].

\subsection{In vitro assay procedures for screening and evaluation of viral assembly inhibitors}

The capsid protein is the building block of virus in which it is surrounded by the nucleic acid and reverse transcriptase. In vitro assay involves the modified capsid protein by eliminating the nucleic acid which is useful for capsid assembly and it is fluorescently labelled by dimerizing the capsid proteins by bringing the residues together resulting in inhibiting the assembly of viral proteins. Another method used here is turbidometric method for screening the assembly of viral protein inhibitors. In this method, it involves the $\mathrm{N}$ terminal part of the protein and the capsid part by mixing the protein and the nucleic acid, and during the assembly, the turbidity is formed. The assembly of viral inhibitors was monitored by measuring the turbidity of the mixture $[72,73]$.

\subsection{In vitro assay procedures for screening and evaluation of viral maturation inhibitors}

The proteases have the tendency to cleave the viral polyprotein precursors to release the functional protein of the virus. The proteases such as papain proteases of coronavirus program the cell signal pathway to inhibit the degradation of viral components. There are many in vitro assays used to determine the protease activity and it involves synthetic peptide, a classical method which mimics the protease activity. Through which the viral protease inhibitors changes the peptide sequence to target the protease site and they can be evaluated by colorimetric and fluorescence method. By this procedure, it is easy to determine the coronavirus protease activity and some of them employed nanoparticles or quantum dots to monitor the analysis of proteolytic products through mass spectrometric methods. An example is in which the cells are transfected with the precursor protease to cleave the cellular protein which results in cell death and apoptosis. These are the in vitro methods which are suitable for screening the antiviral components to target the virus or the proteins $[74,75]$.

\subsection{In vitro analysis of metal nanoparticles}

Most of the studies have reported that the silver nanoparticles are excellent in controlling and preventing various viral diseases. The mechanism of AgNPs is that it prevents the virus from entering the host and also it prevents the virus from binding with the cell receptor (Fig. 2). The important fact of AgNPs is that it deactivates the virus by denaturing the surface 


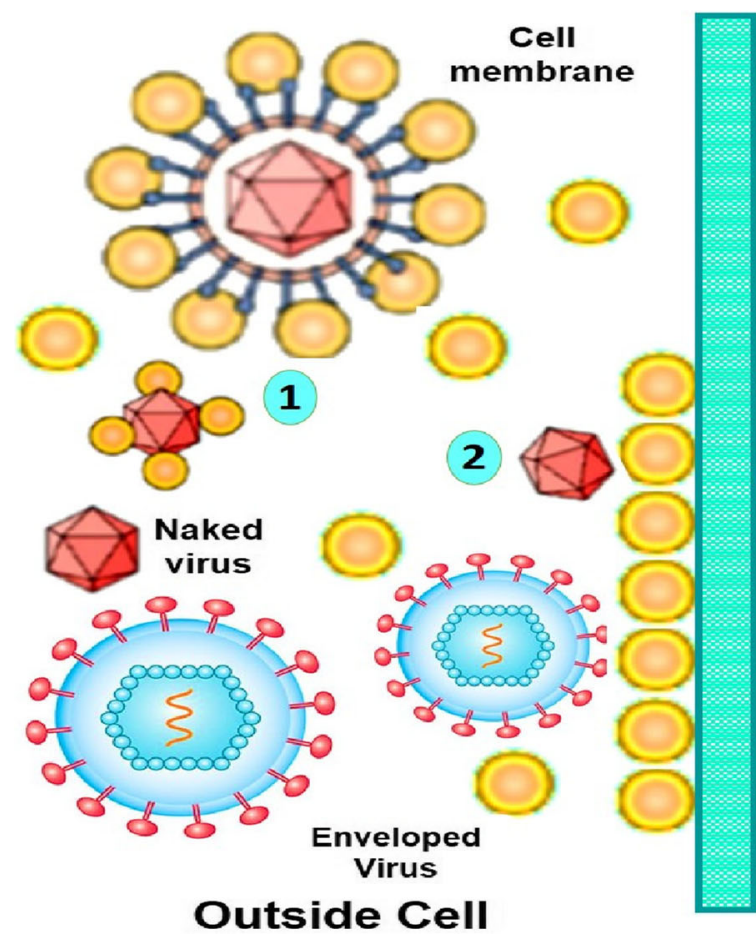

Fig. 2 Potential antiviral mechanism of AgNPs. (1) AgNPs interact with viral envelope and/or viral surface proteins; (2) AgNPs interact with cell membranes and block viral penetration; (3) AgNPs block cellular pathways of viral entry; (4) AgNPs interact with viral genome; (5) AgNPs

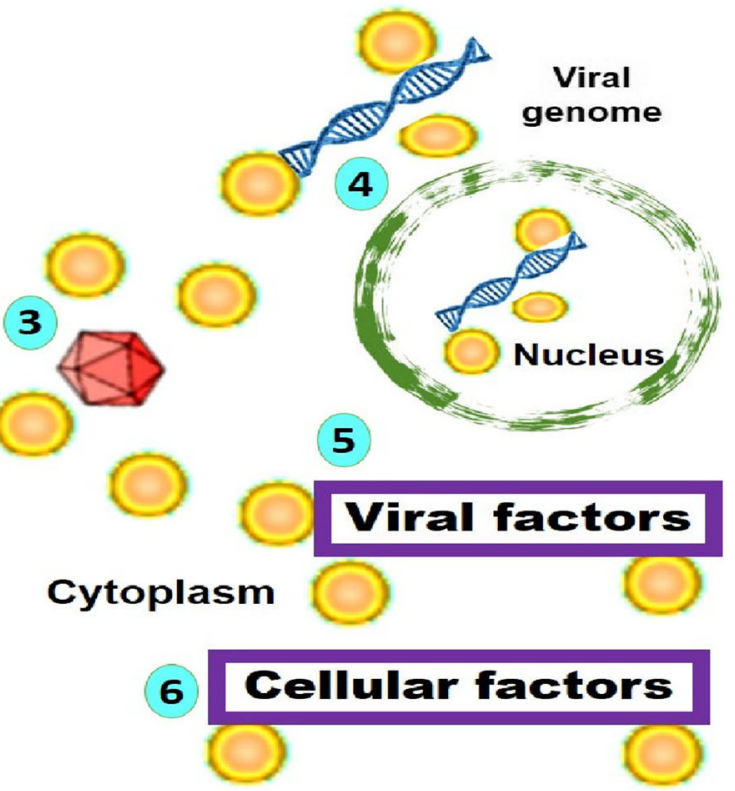

\section{Inside Cell}

interact with viral factors necessary for viral replication; and (6) AgNPs interact with cellular factors necessary for productive viral replication. Reproduced with permission from ref. [76]. Copyright 2016 Taylor and Francis

genetic DNA to inhibit and prevent the cell replication by providing antiviral activity $[79,80]$.

The surface modification of the AgNPs will also show the synergistic antiviral activity. The AgNPs functionalized with biopolymers exhibit an excellent antiviral activity against the viruses. They interact with the viral glycoproteins and inhibit them by preventing their entry into the cells which acts as an effective antiviral activity. This functionalized AgNP blocks the interaction of the virus with the host cells through the electrostatic interactions between the polymer and the virus. It was reported in a study that the curcumin was used as a reducing and the stabilizing agent which prevents the replication and also it blocks the budding of the viruses. It was used as a capping agent in the AgNPs to formulate a stable cAgNPs. This curcumin-capped AgNP reduces the cytopathic effects produced by the virus and showed an excellent antiviral activity by inactivating the virus directly before entering into the host cells. The antiviral action of the functionalized cAgNPs is higher than that of the unmodified AgNPs and curcumin alone [81] (Fig. 3).

There are studies in which they have used drugs (zanamivir, amantadine and oseltamivir) to prepare the surface modified AgNPs through the chemical methods. These studies showed that these functionalized AgNPs can interact with the virus particles directly which results in 
Fig. 3 Schematic representation of the synthesis of cAgNPs (A) and a proposed inhibition mode of cAgNPs against RSV infection (B). The inhibition mode of (B) shows that cAgNPs can reduce the binding ability of virus with the binding centres on the surface of cells (b) as compared to those without cAgNPs (a). Reproduced with permission from ref. [81]. Copyright 2016 Royal Chemistry Society
A

A
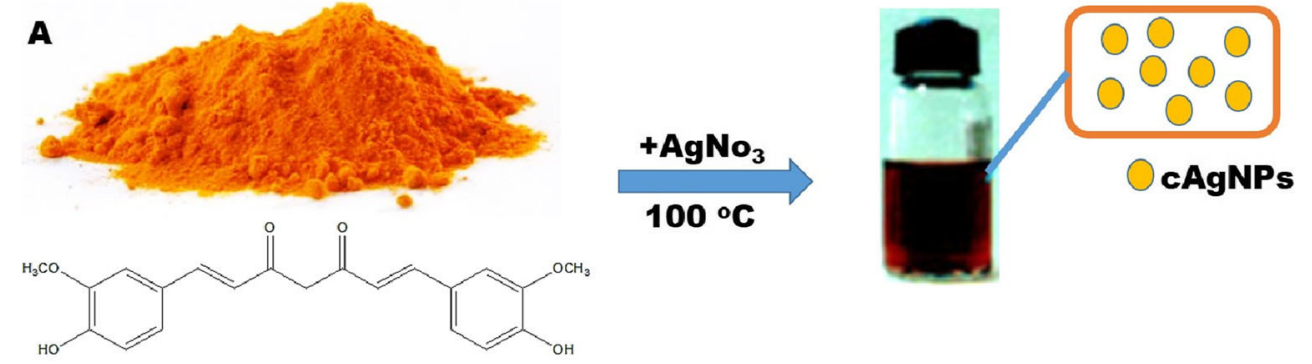

$100^{\circ} \mathrm{C}$
$\mathbf{B}$

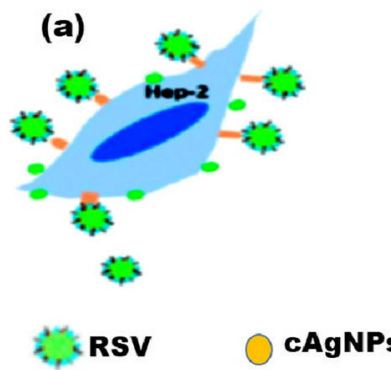

(b)

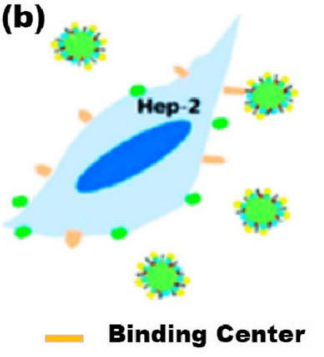

destroying the virus and blocks the entry of virus. Therefore, the antiviral activity depends on the alteration of the capsid structure, surface protein denaturation and the adsorption of virus particle. Moreover, the antiviral activity also depends on the size, shape, surface activity and functionalization of the silver ions to interrupt the virus cycle replication [82-84].

When compared to the silver nanoparticles, gold nanoparticles (AuNPs) exhibit reduced toxicity on the healthy normal cells which makes them more attractive for the in vivo applications. AuNPs interact with the glycoprotein haemagglutinin (HA) in which the Au can able to oxidize the disulfide bond which causes inactivation of the virus [85-87]. To target the HA is a very effective emerging approach particularly for the pandemic viruses which have a much accelerated speed of mutation of the surface proteins. This strategy has been applied to most of the pandemic viruses in which the morphology of the AuNPs plays an important role to inhibit the viral infection more efficiently. The porous AuNPs have the higher surface area which favours the interaction with the capsid by increasing their antiviral activity than the nonporous material. The surface modification of the AuNPs enhances their therapeutic activity by introducing the target ligands during the formulation. In the in vitro conditions, the gold ions with the presence of gallic acid produce a homogenous AuNPs to inhibit the viral infection. The functionalized AuNPs have many benefits like higher circulation time and low concentration, which has the specific patterns to target the virus. Usually, the negative charge is used to imitate the cell surface and the molecular patterns are useful in targeting the virus [88-90]. The sulphonate and the organic sulphates were used to interact with the capsid proteins of the virus cell and prevent the HA activity. The sulphonate functionalized AuNPs exhibited an increased inhibition of virus when compared to the succinic acid functionalized one. In a study, it is reported that the thiol functionalized AuNPs showed a very powerful inhibition of virus in the in vitro conditions. Functionalized AuNPs can able to prevent the replication of virus even at a very less concentration and also reduce the $\mathrm{IC}_{50}$ of about 2 orders of magnitude [91].

The main benefits of using NPs are they release the ions and clusters very slowly from the particles which lead to the improved antiviral activity. In addition, the metal nanoparticles like copper and iron in the form of ions will generate the radicals through Fenton-like reactions, which oxidizes the capsid proteins and also inhibits the virus replication at the early stage. For example, copper ions in the form of sulphates and iodides were widely used as antiviral agents because they act on all kinds of viruses $[92,93]$. It mainly depends on the formation of ions $\left(\mathrm{Cu}^{+}\right)$which are derived from the iodide or the sulphates were used as the antiviral components because of its action on the enveloped and non-enveloped viruses. The main mechanism is that it purely depends on the $\mathrm{Cu}^{+}$ions from the nanoparticles which generate the hydroxyl radicals. Cuprous and cupric oxide nanoparticles have extensively used as antiviral components for the in vitro applications. It shows that the $\mathrm{Cu}$ nanoparticle has an excellent antiviral activity without cytotoxicity by binding and entering the host against the viruses [94, 95]. A $\mathrm{ZnO}$ nanoparticle is another antiviral agent having a tetrapod morphology in which it mimics the cell surface by interacting with the viral capsid. By photocatalysis method, it destroys or inhibit the viral proteins upon UV radiation [96]. 


\subsection{In vitro analysis of carbon-based nanomaterials}

The carbon-based nanomaterials showed a tremendous increase in the field of antiviral activity. Fullerene and its derivatives are the most researched carbon nanomaterials in the field of antivirals. Because of its low solubility, functionalization method is used to increase the solubility, and by modifying its shape and function, fullerene derivatives possess antiviral properties by inhibiting the entry of virus and replication. Mostly, carbon dots and the graphene oxide are used as antiviral components to prevent the entry of virus in the host cells. An example is that glycofullerenes were made into a supramolecular formulation which leads to the formation of micelles. These micelles are spherically shaped and more uniform and the aggregation synthetic route enables a controlled preparation of giant molecule glycofullerenes [97] (Fig. 4). The functionalized self-assembled $\mathrm{C}_{60}$ with the mannose units has the carbohydrate on the surface which leads to inhibit the virus. The in vitro studies displayed a good biocompatibility and produce the promising results against the SARS-CoV. The functionalized fullerenes compete with the virus by the lectin receptors and they have large amount of mannose to improve the multivalency and increase the therapeutic activity (Fig. 4). These glycofullerenes can decrease the infectivity but they are capable of inactivating the virus to a large extent. Moreover, the mechanism of action depends on the interaction with the host cells, and while injected at the different time intervals, it prevents the virus from damaging the host cells. The well-developed surface chemistry of the glycofullerenes was very effective in the current pandemic virus SARS-CoV-2 which involves the click chemistry strategy to anchor the ligands by inhibiting the virus [98, 99].

The carbon dots (CDs) are zero-dimensional particle which is prepared by the hydrothermal decomposition method. They have less toxicity, easily functionalized and have fluorescence properties. The carbon dot prevents the viral infection in the in vitro analysis and it has the hydroxyl and carboxyl groups on the surface which interacts with the membrane of the virus [100]. Antiviral agents are grafted on the surface of the CDs to improve its activity which involves the two-step

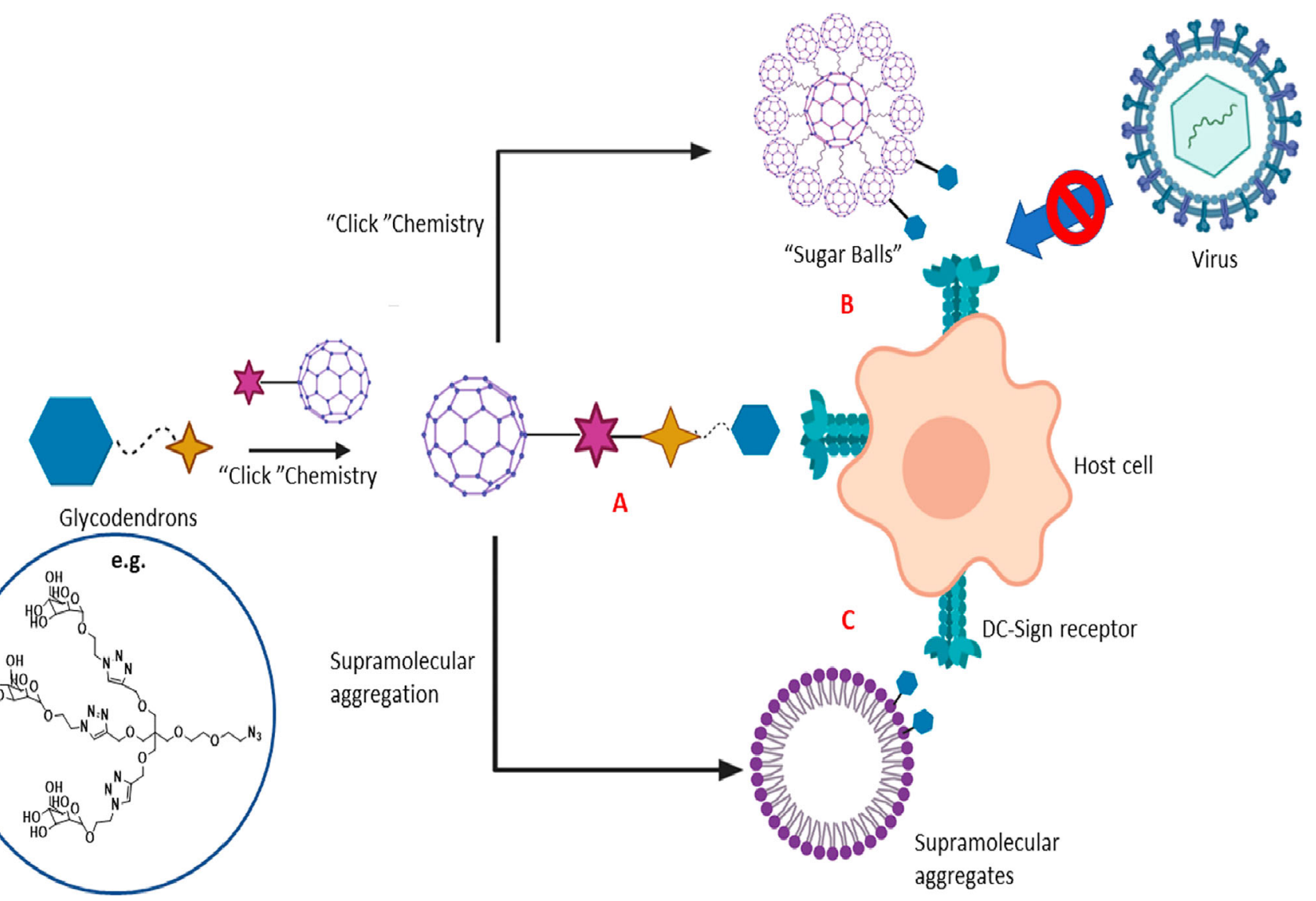

Fig. 4 Chemical design and general scheme to block the viral entry by glycofullerenes. Three different shapes of glycofullerenes can act as inhibitor of viral infection: (A) shape composed of monodisperse fullerene bearing mannose, (B) assembly as "sugar balls" of tridecafullerenes

exhibiting mannose on the edges, and (C) supramolecular micellar aggregates of fullerenes bearing mannose. Reproduced with permission from Ref [55] (copyright permission from ACS nano) 
reaction. In the first step, it consists of addition of the antiviral agent directly in the preparation process by generating a preferred functional $\mathrm{CD}$. Then, hydrothermal treatment is initiated to the process which alters the chemical structure of the therapeutic moiety. The second step involves a two-step process in which it undergoes post functionalization through amide formation on the surface of the CDs which are rich in the carboxylic groups. The functionalized antiviral agent shows the inhibition of virus into the cell which has the broadspectrum action for the enveloped and the nonenveloped viruses (Fig. 5). The results obtained were due to the efficient binding of the CDs to the virus and thereby inhibiting its replication [101, 102].

The graphene-based materials such as graphene oxide (GO) and reduced graphene oxide (rGO) have been used for biomedical applications. GO will block the entry of virus in the host cells and they are called as two-dimensional materials which contain hydrophobic and hydrophilic domains which adsorb the nucleic acids and proteins. This GO can be used as a photothermal agent and also used in photodynamic therapy which involves in deactivating the viral capsids through the irradiation and thermal shock [103, 104]. GO along with the antiviral agent were functionalized and used for the treatment of the viral infection. They have used organic and metal nanoparticles for the functionalization to prevent the viral infection in the host cell by binding with the viral membrane. The rGO-FeNP involves the photothermal therapy for the treatment of all kinds of viruses in which it strongly adsorbs proteins (coronation) by inhibiting the viral entry to the cells $[105,106]$.

\subsection{In vivo analysis}

In the in vivo analysis, the selenium nanoparticles (SeNPs) were studied for the antiviral efficiency. They completely depend on the decrease in the concentration of ROS in the host cells. This method alleviates the toxicity by improving the cell viability through the antiviral activity. This method prevents the viral infection and also the survival of the host cell [107]. The main mechanism of action is that these nanoparticles completely depend on the quenching of free radicals in the host because of the infection, preventing the mitochondrial depolarization and apoptosis. The SeNP adsorbs on the surface of viral capsid by reducing the infection and it is prepared by the mixing the Se salt with the presence of reducing agent. The SeNPs were functionalized with the drug molecule and they are used to prevent the viral entry to the cell which is administered through intranasal route for 3 days of every $24 \mathrm{~h}$ [107-110]. The results showed that the infected mice had recovered from the alveolar collapse and perivascular and peribronchiolar edema compared to

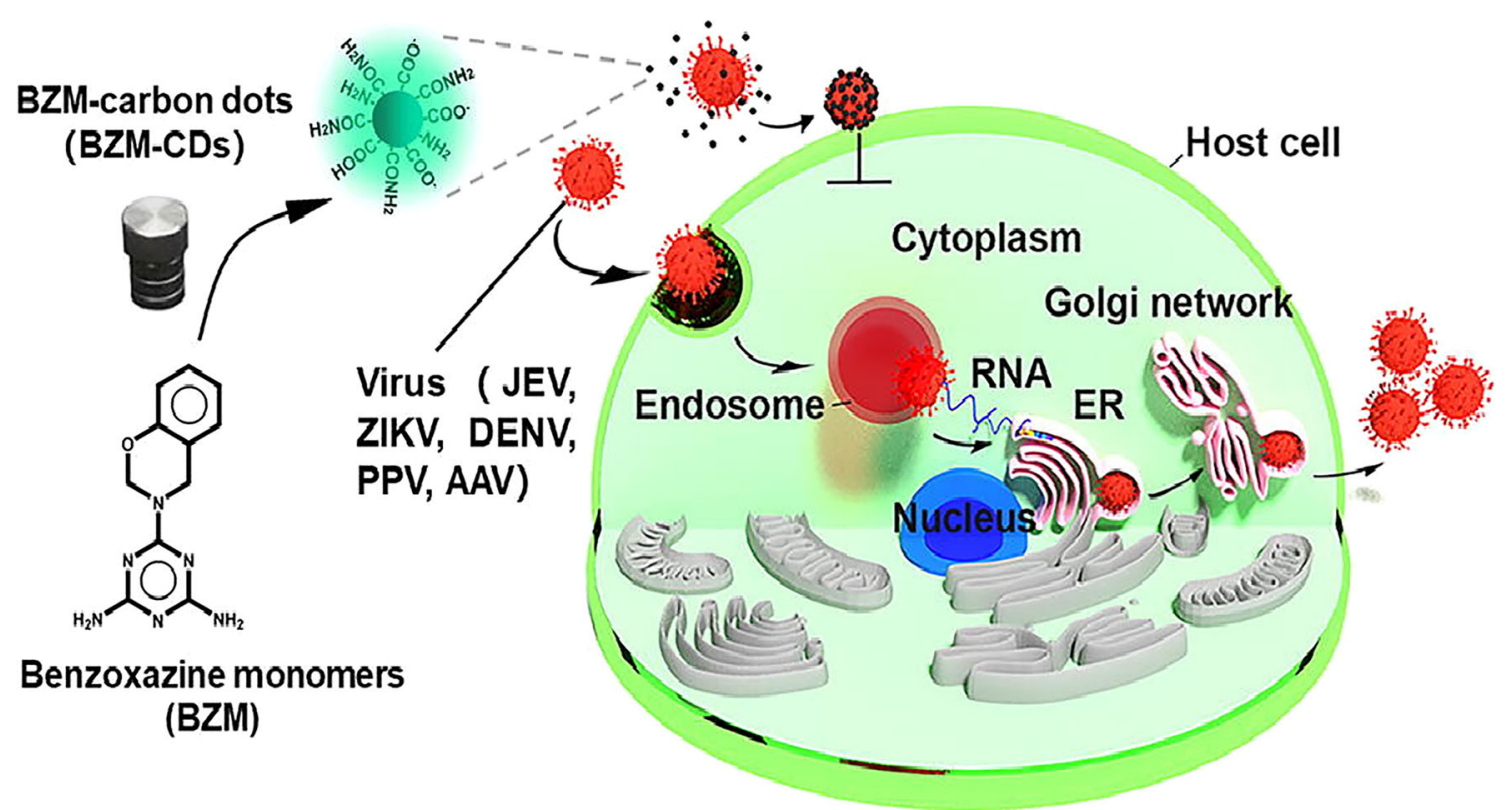

Fig. 5 Illustration of benzoxazine-functionalized CDs and their broad antiviral entry activity. Reproduced with permission from ref. [101]. Copyright 2019 Elsevier B.V 
the other groups. Owing to its very low cytotoxicity and efficacy, the SeNPs are considered an efficient component for treating the viral disease such as SARS-Cov-2. The symptoms of COVID-19 lead to chronic inflammation and the oxidative stress results in the spread of infection. Hence, the use of SeNPs eradicates the toxicity of infected persons and it reacts against the contagious virus (Fig. 6). The biosafety and long-term toxicity are the important challenges to be studied for the clinical translation [111, 112].

The use of nanoparticles with similar size of virus improves the immune response in the host cells. It adsorbs the viral particles and presents it to the immune system and these nanomaterials were administered in the in vivo conditions and tested for its efficiency. The ZnO NP which has the tetrapod morphology is inoculated with the virus and it can able to prevent the cell adhesion to display the viral antigens to the $\mathrm{T}$ cells. The in vivo study showed that it has $90 \%$ antiviral activity and it mimics the couple cells (Fig. 7) [113, 114].

The calcium phosphate nanoparticles (CaPNPs) were functionalized covalently with the lysozyme which shows an immunization 100 times higher when given a subdermal injection in mice. For the iron oxide nanoparticles, they have given two subdermal injections to the mice for 14 days and they exhibited the block in the entry to the cell [115]. The CaPNPs were covalently modified with the alum and two peptides were adjuvant and the antigens. The nanomaterials highly stimulate the immune system which generates the efficient antibodies to block the cell from the infection by the virus ( 3 I.M injection for every mice for 14 days). Therefore, the nanomaterials increase the survival rate of about $100 \%$ when compared to controls (Fig. 8) [116, 117].

\section{Conclusion}

Since the discovery of nanoparticle, nanotechnology has wide range of application due to having high surface area to volume ratio. The nanoscale product has also helped in development of new field to study the use of the same. Traditional technique of PCR and sequencing is a timeconsuming process of detection of virus and may show
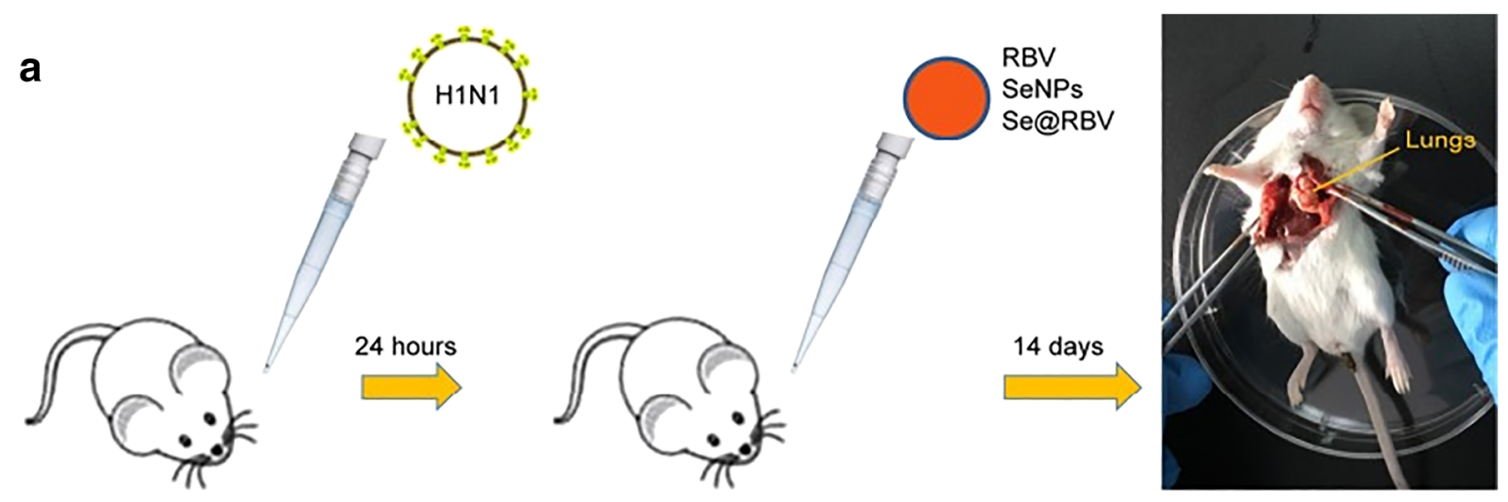

b
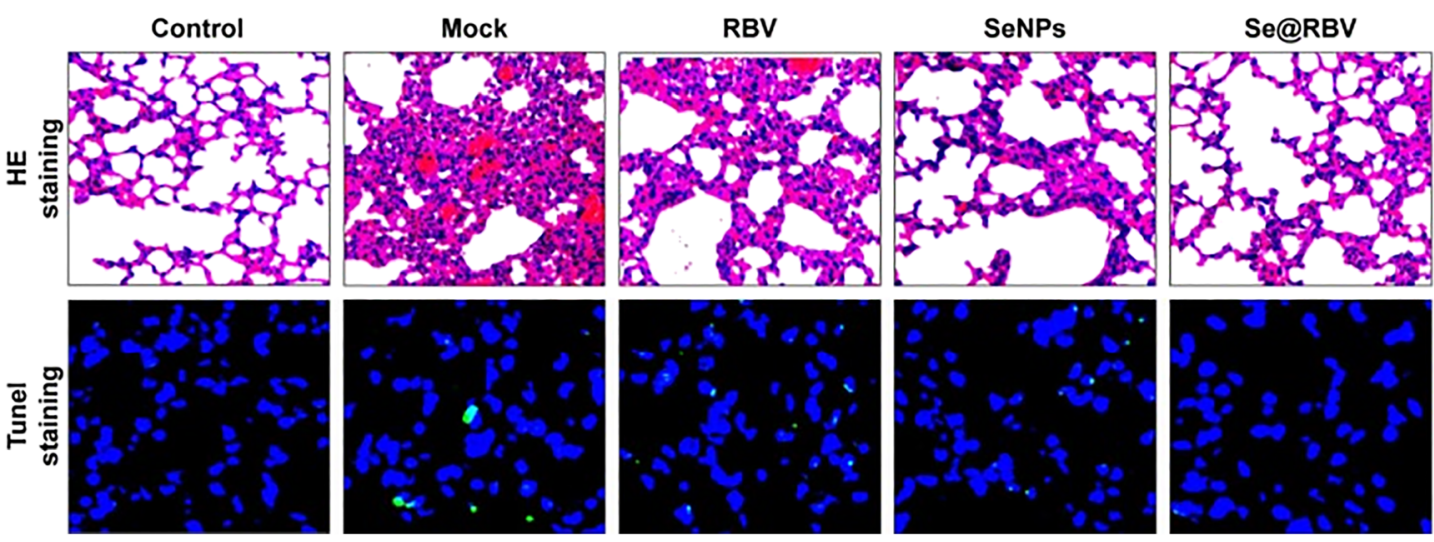

Fig. 6 In vivo antiviral efficiency of SeNPs functionalized with ribavirin (Se@RBV). a Mice infected by H1N1 virus were treated with physiological saline (Mock), RBV, SeNPs, or Se@RBV. b H\&E and

tunnel staining showing that Se@RBV-treated mice displayed reduced lung damages compared to Mock. Reproduced with permission from ref. [107]. Copyright 2018 Dove Press Ltd.

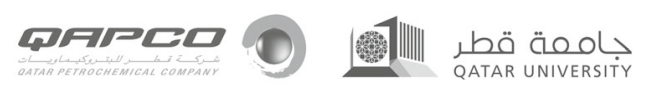


a

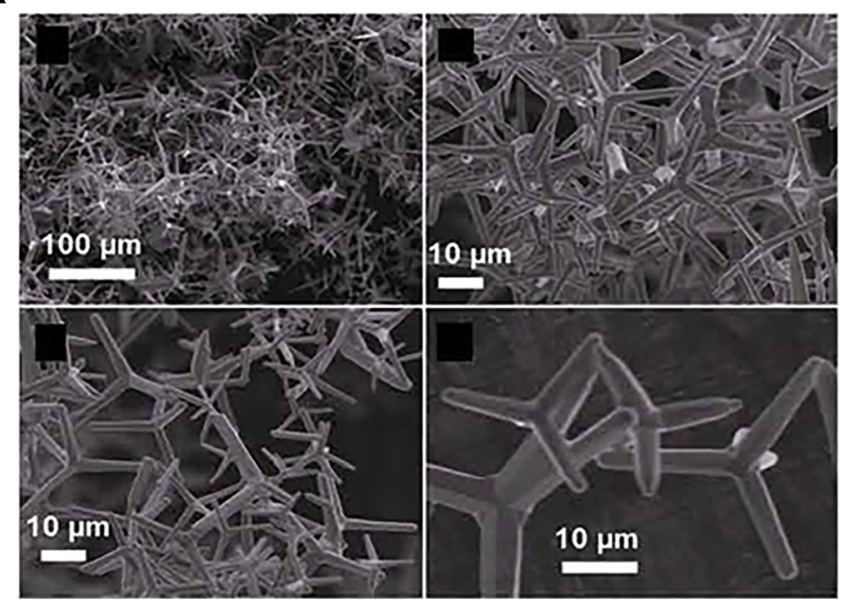

b

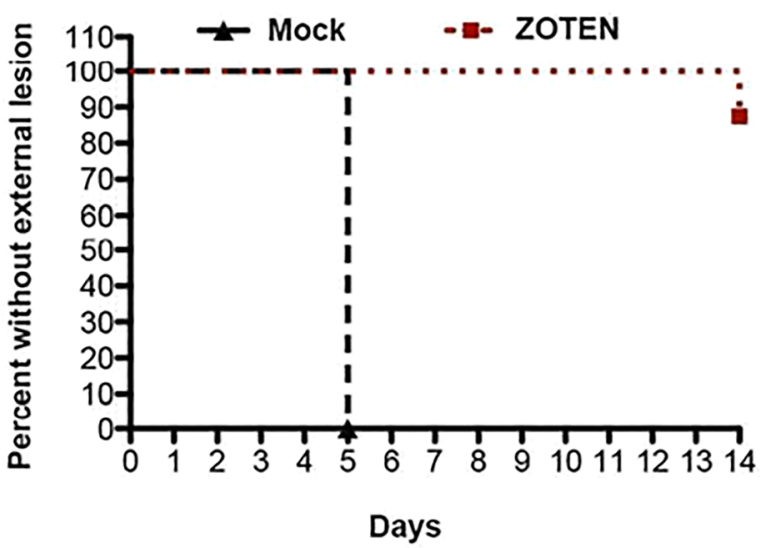

C

Day 1
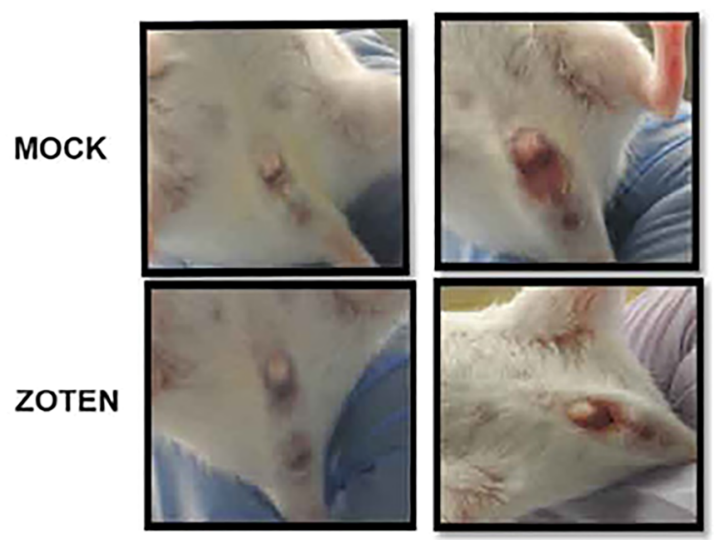

Fig. 7 a Scanning electron microscopy images of $\mathrm{ZnO}$ tetrapod nanoparticles (ZOTEN) synthesized by flame transport synthesis. b Mice were challenged intravaginally with HSV-2333 with or without ZOTEN. c To monitor progression of infection, mice were observed daily individual specific false outcome. The variation of PCR technique has been discussed in order to develop fast and specific detection of SARS-CoV-2 that is responsible for ongoing pandemic. ELISA is very fast, specific and highly sensitive detection system for diagnosis of patient infected with SARS-CoV-2. CRISPER-cas technique is recently discovered edited tools which have potential to detect very low $1.7 \mathrm{fM}$ concentration of nucleic acid within $15 \mathrm{~min}$. Currently, the uses of nanomedicines which enable to enhance the therapeutic effect of drugs reduce the toxicity level. The uses of nanotechnology-based medicine have demonstrated the significant improvement of therapeutic care of various diseases from cancer to infection. During the pandemic, a scientist has experienced extensive knowledge gained over the years; the nanotechnology has played a key role in COVID-19 management. The appropriate knowledge of nanotechnology has assisted in the development of rapid and effective diagnostic system for COVID-19. During the COVID-19 pandemic, there is urgency of extensive study which needs to be done in order to develop nanotechnology-based therapeutic drugs to prevent the novel corona virus.

Author contributions AT and PP conceived the original idea and designed the review paper. AT and RR contributed equally and wrote the manuscript in consultation with the help of AK, MDC and PP. ST corrected the final manuscript. All the authors approved the submitted version.

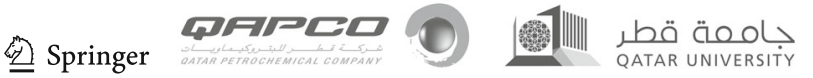




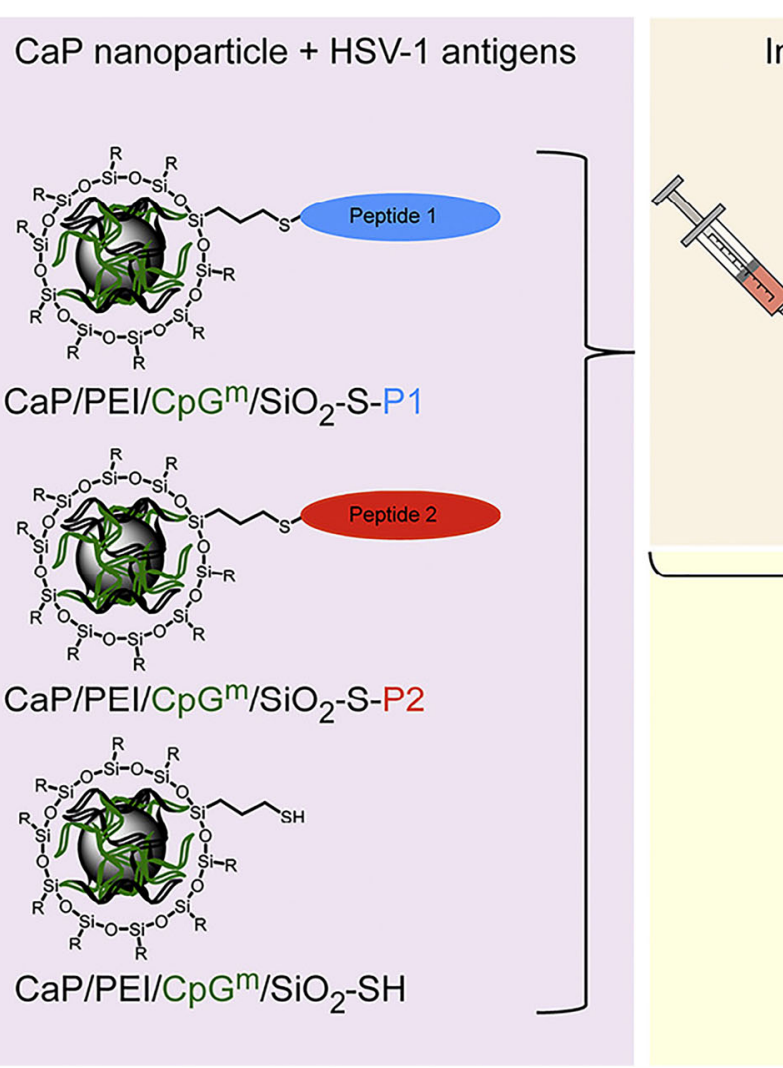

Fig. 8 Scheme of CaPNPs used for vaccine. Left: CaPNPs functionalized with $\mathrm{CpGm}$ adjuvant and two different peptides as antigens. Top right: CaPNPs were able to reduce cell-to-cell virus spread in vitro. Bottom

\section{Declarations}

Conflict of interest The authors declare no competing interests.

\section{References}

1. V.K. Viswanathan, S.R. Rajaram Manoharan, S. Subramanian, A. Moon, Nanotechnology in spine surgery: a current update and critical review of the literature. World Neurosurg. 123, 142-155 (2019)

2. V. Kumar, S. Palazzolo, S. Bayda, G. Corona, G. Toffoli, F. Rizzolio, DNA nanotechnology for cancer therapy. Theranostics 6, 710 (2016)

3. S. Madhurantakam, K.J. Babu, J.B.B. Rayappan, U.M. Krishnan, Nanotechnology-based electrochemical detection strategies for hypertension markers. Biosens. Bioelectron. 116, 67-80 (2018)

4. M.J. Espy, J.R. Uhl, L.M. Sloan, S.P. Buckwalter, M.F. Jones, E.A. Vetter, J.D.C. Yao, N.L. Wengenack, J.E. Rosenblatt, F.R. Cockerill, T.F. Smith, Realtime PCR in clinical microbiology: applications for routine laboratory testing. Clin. Microbiol. Rev. 19, 165-256 (2006)

5. J. Van Elslande, B. Decru, S. Jonckheere, E. Van Wijngaerden, E. Houben, P. Vandecandelaere, C. Indevuyst, M. Depypere, S. Desmet, E. André, M. Van Ranst, K. Lagrou, P. Vermeersch, Antibody response against SARS-CoV-2 spike protein and nucleoprotein evaluated by four automated immunoassays and three ELISAs. Clin. Microbiol. Infect. 26, 1557-15e1 (2020) mmunization of mice

Induction of HSV-1 cell-to-cell spread inhibiting antibodies
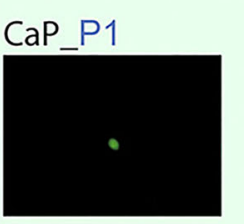

CaP_P2

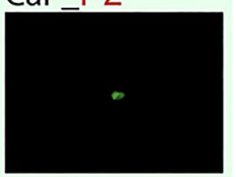

Mock

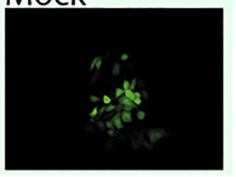

Protection from lethal HSV-1 infection

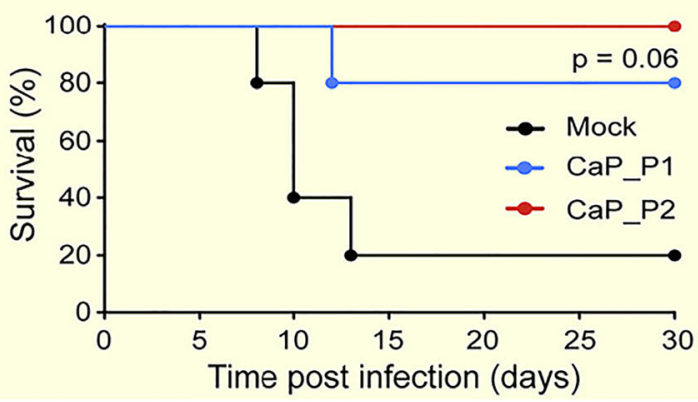

right: $\mathrm{CaP}$ nanoparticles were able to immunize mice against HSV-1. Reproduced with permission from ref. [116]. Copyright 2019 Elsevier B.V

6. V. Roy, S. Fischinger, C. Atyeo, M. Slein, C. Loos, A. Balazs, C. Luedemann, M.G. Astudillo, D. Yang, D.R. Wesemann, R. Charles, A.J. Lafrate, J. Feldman, B. Hauser, T. Caradonna, T.E. Miller, M.R. Murali, L. Baden, E. Nilles, E. Ryan, D. Lauffenburger, W.G. Beltran, G. Alter, SARS-CoV-2-specific ELISA development. J. Immunol. Methods 484, 112832 (2020)

7. B.S. Chhikara, B. Rathi, J. Singh, Poonam, Corona virus SARSCoV-2 disease COVID-19: Infection, prevention and clinical advances of the prospective chemical drug therapeutics. Chem. Biol. Lett. 7, 63-72 (2020)

8. W. Wang, T. Wang, Y. Deng, P. Niu, R. A, J. Zhao, M. Peiris, S. Tang, W. Tan, A novel luciferase immunosorbent assay performs better than a commercial enzyme-linked immunosorbent assay to detect MERS-CoV specific IgG in humans and animals. Biosafety and Health 1, 134-143 (2019)

9. D. Budhadev, E. Poole, I. Nehlmeier, Y. Liu, J. Hooper, E. Kalverda, U.S. Akshath, N. Hondow, W.B. Turnbull, S. Pöhlmann, Y. Guo, D. Zhou, Glycan-gold nanoparticles as multifunctional probes for multivalent lectin-carbohydrate binding: implications for blocking virus infection and nanoparticle assembly. J. Am. Chem. Soc. 142, 18022-18034 (2020)

10. O.O. Onabajo, A.R. Banday, M.L. Stanifer, W. Yan, A. Obajemu, D.M. Santer, O. Florez-Vargas, H. Piontkivska, J.M. Vargas, T.J. Ring, C. Kee, P. Doldan, D.L. Tyrrell, J.L. Mendoza, S. Boulant, L. Prokunina-Olsson, Interferons and viruses induce a novel truncated ACE2 isoform and not the fulllength SARS-CoV-2 receptor. Nat. Genet. 52, 1283-1293 (2020)

11. M. Hussain, N. Jabeen, F. Raza, S. Shabbir, A.A. Baig, A. Amanullah, B. Aziz, Structural variations in human ACE2 may 
influence its binding with SARSCoV-2 spike protein. J. Med. Virol. 92, 1580-1586 (2020)

12. B. Giri, S. Pandey, R. Shrestha, K. Pokharel, F.S. Ligler, B.B. Neupane, Review of analytical performance of COVID-19 detection methods. Anal. Bioanal. Chem. 1-14 (2020)

13. M. Tré-Hardy, A. Wilmet, I. Beukinga, J. Favresse, J.M. Dogné, J. Douxfils, L. Blairon, Analytical and clinical validation of an ELISA for specific SARSCoV-2 IgG, IgA, and IgM antibodies. J. Med. Virol. 93, 803-811 (2021)

14. D. Jacofsky, E.M. Jacofsky, M. Jacofsky, Understanding antibody testing for COVID-19. J. Arthroplast. 35, S74-S81 (2020)

15. I.D.L. Cavalcanti, M. Cajubá de Britto Lira Nogueira, Pharmaceutical nanotechnology: which products are been designed against COVID-19? J. Nanopart. Res. 22, 1-11 (2020)

16. P. Moitra, M. Alafeef, M. Alafeef, M. Alafeef, K. Dighe, M.B. Frieman, D. Pan, D. Pan, D. Pan, Selective naked-eye detection of SARS-CoV-2 mediated by $\mathrm{N}$ gene targeted antisense oligonucleotide capped plasmonic nanoparticles. ACS Nano. 14, 7617-7627 (2020)

17. M. Cheng, Y. Zhang, X. Zhang, W. Wang, Z. Yuan, One-pot synthesis of acid-induced: in situ aggregating theranostic gold nanoparticles with enhanced retention in tumor cells. Biomater. Sci. 7, 2009-2022 (2019)

18. C. Huang, T. Wen, F.J. Shi, X.Y. Zeng, Y.J. Jiao, Rapid detection of IgM antibodies against the SARS-CoV-2 virus via colloidal gold nanoparticle-based lateral-flow assay. ACS Omega 5, 12550-12556 (2020)

19. M. Srivastava, N. Srivastava, P.K. Mishra, B.D. Malhotra, Prospects of nanomaterials-enabled biosensors for COVID-19 detection. Sci. Total. Environ. 754, 142363 (2021)

20. X. Zhu, X. Wang, L. Han, T. Chen, L. Wang, H. Li, S. Li, L. He, X. Fu, S. Chen, M. Xing, H. Chen, Y. Wang, Multiplex reverse transcription loopmediated isothermal amplification combined with nanoparticle-based lateral flow biosensor for the diagnosis of COVID-19. Biosens. Bioelectron. 166, 112437 (2020)

21. H. Ryu, J.L. Cashdollar, G.S. Fout, K.A. Schrantz, S. Hayes, Applicability of integrated cell culture quantitative PCR (ICCqPCR) for the detection of infectious adenovirus type 2 in UV disinfection studies. J. Environ. Sci. Health A Tox. Hazard. Subst. Environ. Eng. 50, 777-787 (2015)

22. C. Techathuvanan, D.H. D'Souza, Propidium monoazide for viable salmonella enterica detection by PCR and LAMP assays in comparison to RNA-based RT-PCR, RT-LAMP, and culturebased assays. J. Food. Sci. 85, 3509-3516 (2020)

23. K. Chrzastek, D.h. Lee, D. Smith, P. Sharma, D.L. Suarez, M. Pantin-Jackwood, D.R. Kapczynski, Use of SequenceIndependent, Single-Primer-Amplification (SISPA) for rapid detection, identification, and characterization of avian RNA viruses. Virology 509, 159-166 (2017)

24. G.R. Reyes, J.P. Kim, Sequence-independent, single-primer amplification (SISPA) of complex DNA populations. Mol. Cell. Probes 5, 473-481 (1991)

25. A. Kędrak-Jabłońska, S. Budniak, M. Krupa, A. Szczawińska, M. Reksa, K. Szulowski, W. Iwaniak, Detection of Listeria spp. and Listeria monocytogenes in biological samples by SYBR Green I and TaqMan probe-based real-time PCRs. J. Vet. Res. 61, 427$432(2017)$

26. Y. Yan, J.Y. Luo, Y. Chen, H.H. Wang, G.Y. Zhu, P.Y. He, J.L. Guo, Y.L. Lei, Z.W. Chen, A multiplex liquid-chip assay based on Luminex xMAP technology for simultaneous detection of six common respiratory viruses. Oncotarget 8, 96913 (2017)

27. Y. Jiang, L. Fang, X. Shi, H. Zhang, Y. Li, Y. Lin, Y. Qiu, Q. Chen, H. Li, L. Zhou, Q. Hu, Simultaneous detection of five enteric viruses associated with gastroenteritis by use of a PCR assay: a single real-time multiplex reaction and its clinical application. J. Clin. Microbiol. 52, 1266-1268 (2014)
28. A. Stevenson, A. Kirresh, S. Conway, L. White, M. Ahmad, C. Little, Hydroxychloroquine use in COVID-19: is the risk of cardiovascular toxicity justified. Open Heart 7, e001362 (2020)

29. D.A. Jans, K.M. Wagstaff, Ivermectin as a broad-spectrum hostdirected antiviral: the real deal? Cells 9, 2100 (2020)

30. A. Chowdhury, S. Kunjiappan, T. Panneerselvam, B. Somasundaram, C. Bhattacharjee, Nanotechnology and nanocarrier-based approaches on treatment of degenerative diseases. Int. Nano. Lett. 7, 91-122 (2017)

31. S. Sur, A. Rathore, V. Dave, K.R. Reddy, R.S. Chouhan, V. Sadhu, Recent developments in functionalized polymer nanoparticles for efficient drug delivery system. Nano-Struct NanoObjects 20, 100397 (2019)

32. D. Sergeevichev, V. Fomenko, A. Strelnikov, A. Dokuchaeva, M. Vasilieva, E. Chepeleva, Y. Rusakova, S. Artemenko, A. Romanov, N. Salakhutdinov, A. Chernyavskiy, Botulinum toxin-chitosan nanoparticles prevent arrhythmia in experimental rat models. Mar. Drugs 18, 410 (2020)

33. Y. Dhayanandamoorthy, M.G. Antoniraj, C.A.B. Kandregula, R. Kandasamy, Aerosolized hyaluronic acid decorated, ferulic acid loaded chitosan nanoparticle: a promising asthma control strategy. Int. J. Pharm. 591, 119958 (2020)

34. O.M. Kolawole, W.M. Lau, V.V. Khutoryanskiy, Methacrylated chitosan as a polymer with enhanced mucoadhesive properties for transmucosal drug delivery. Int. J. Pharm. 550, 123-129 (2018)

35. S. Villapol, Gastrointestinal symptoms associated with COVID19: impact on the gut microbiome. Transl. Res. (2020)

36. Q. Zhang, A. Honko, J. Zhou, H. Gong, S.N. Downs, J.H. Vasquez, R.H. Fang, W. Gao, A. Griffiths, L. Zhang, Cellular nanosponges inhibit SARS-CoV-2 infectivity. Nano. Lett. 20, 5570-5574 (2020)

37. S.H. Nile, A. Nile, J. Qiu, L. Li, X. Jia, G. Kai, COVID-19: pathogenesis, cytokine storm and therapeutic potential of interferons. Cytokine Growth Factor Rev. 53, 66-70 (2020)

38. F. Leuschner, P. Dutta, R. Gorbatov, T.I. Novobrantseva, J.S. Donahoe, G. Courties, K.M. Lee, J.I. Kim, J.F. Markmann, B. Marinelli, P. Panizzi, W.W. Lee, Y. Iwamoto, S. Milstein, H. Epstein-Barash, W. Cantley, J. Wong, V. Cortez-Retamozo, A. Newton, K. Love, P. Libby, M.J. Pittet, F.K. Swirski, V. Koteliansky, R. Langer, R. Weissleder, D.G. Anderson, M. Nahrendorf, Therapeutic siRNA silencing in inflammatory monocytes in mice. Nat. Biotechnol. 29, 1005-1010 (2011)

39. M. Zhao, Cytokine storm and immunomodulatory therapy in COVID-19: role of chloroquine and anti-IL-6 monoclonal antibodies. Int. J. Antimicrob. Agents (2020)

40. F. Dormont, R. Brusini, C. Cailleau, F. Reynaud, F. Reynaud, A. Peramo, A. Gendron, J. Mougin, F. Gaudin, F. Gaudin, M. Varna, P. Couvreur, Squalene-based multidrug nanoparticles for improved mitigation of uncontrolled inflammation in rodents. Sci. Adv. 6, 5466 (2020)

41. A. Łoczechin, K. Séron, A. Barras, E. Giovanelli, S. Belouzard, Y.T. Chen, N. Metzler-Nolte, R. Boukherroub, J. Dubuisson, S. Szunerits, Functional carbon quantum dots as medical countermeasures to human coronavirus. ACS Appl Mater Interfaces 11, 42964-42974 (2019)

42. E. Morales-Narváez, C. Dincer, The impact of biosensing in a pandemic outbreak: COVID-19. Biosens. Bioelectron 163, 112274 (2020)

43. M. Soler, M.C. Estevez, M. Cardenosa-Rubio, A. Astua, L.M. Lechuga, How nanophotonic label-free biosensors can contribute to rapid and massive diagnostics of respiratory virus infections: COVID-19 Case. ACS Sensors 5, 2663-2678 (2020)

44. J.H. Bong, T.H. Kim, J. Jung, S.J. Lee, J.S. Sung, C.K. Lee, M.J. Kang, H.O. Kim, J.C. Pyun, Pig Sera-derived Anti-SARS-CoV-2 antibodies in surface plasmon resonance biosensors. Biochip. J. 14, 358-368 (2020) 
45. C.C. Lai, T.P. Shih, W.C. Ko, H.J. Tang, P.R. Hsueh, Severe acute respiratory syndrome coronavirus 2 (SARS-CoV-2) and coronavirus disease-2019 (COVID-19): The epidemic and the challenges. Int. J. Antimicrob Agents 55, 105924 (2020)

46. G. Seo, G. Lee, M.J. Kim, S.H. Baek, M. Choi, K.B. Ku, C.S. Lee, S. Jun, D. Park, H.G. Kim, S.J. Kim, J.O. Lee, B.T. Kim, E.C. Park, S. Kim II, Rapid detection of COVID-19 causative virus (SARS-CoV-2) in human nasopharyngeal swab specimens using field-effect transistor-based biosensor. ACS Nano 14, 5135-5142 (2020)

47. M. Aminul Islam, M. Ziaul Ahsan, Plausible approach for rapid detection of SARS-CoV-2 virus by magnetic nanoparticle based biosensors. Am J Nanosci 6, 6-13 (2020)

48. S. Mahari, A. Roberts, D. Shahdeo, S. Gandhi, eCovSens-ultrasensitive novel in-house built printed circuit board based electrochemical device for rapid detection of nCovid-19 antigen, a spike protein domain 1 of SARS-CoV-2 (2020)

49. B.S. Vadlamani, T. Uppal, S.C. Verma, M. Misra, Functionalized tio2 nanotube-based electrochemical biosensor for rapid detection of sars-cov-2. Sensors (Switzerland) 20, 5871 (2020)

50. Y. Li, S. Li, J. Wang, G. Liu, CRISPR/Cas systems towards nextgeneration biosensing. Trends Biotechnol 37, 730-743 (2019)

51. R. Hajian, S. Balderston, T. Tran, T. deBoer, J. Etienne, M. Sandhu, N.A. Wauford, J.Y. Chung, J. Nokes, M. Athaiya, J. Paredes, R. Peytavi, B. Goldsmith, N. Murthy, I.M. Conboy, K. Aran, Detection of unamplified target genes via CRISPR-Cas9 immobilized on a graphene field-effect transistor. Nat Biomed Eng 3, 427-437 (2019)

52. J.J. Lee, R. Wedow, A. Okbay, E. Kong, O. Maghzian, M. Zacher, T.A. Nguyen-Viet, P. Bowers, J. Sidorenko, R.K. Linnér, M.A. Fontana, T. Kundu, C. Lee, H. Li, R. Li, R. Royer, P.N. Timshel, R.K. Walters, E.A. Willoughby, L. Yengo, M. Agee, B. Alipanahi, A. Auton, R.K. Bell, K. Bryc, S.L. Elson, P. Fontanillas, D.A. Hinds, J.C. McCreight, K.E. Huber, N.K. Litterman, M.H. McIntyre, J.L. Mountain, E.S. Noblin, C.A.M. Northover, S.J. Pitts, J.F. Sathirapongsasuti, O.V. Sazonova, J.F. Shelton, S. Shringarpure, C. Tian, V. Vacic, C.H. Wilson, J.P. Beauchamp, T.H. Pers, C.A. Rietveld, P. Turley, G.B. Chen, V. Emilsson, S.F.W. Meddens, S. Oskarsson, J.K. Pickrell, K. Thom, P. Timshel, R. de Vlaming, A. Abdellaoui, T.S. Ahluwalia, J. Bacelis, C. Baumbach, G. Bjornsdottir, J.H. Brandsma, M.P. Concas, J. Derringer, N.A. Furlotte, T.E. Galesloot, G. Girotto, R. Gupta, L.M. Hall, S.E. Harris, E. Hofer, M. Horikoshi, J.E. Huffman, K. Kaasik, I.P. Kalafati, R. Karlsson, A. Kong, J. Lahti, S.J. van der Lee, C. de Leeuw, P.A. Lind, K.O. Lindgren, T. Liu, M. Mangino, J. Marten, E. Mihailov, M.B. Miller, P.J. van der Most, C. Oldmeadow, A. Payton, N. Pervjakova, W.J. Peyrot, Y. Qian, O. Raitakari, R. Rueedi, E. Salvi, B. Schmidt, K.E. Schraut, J. Shi, et al., Gene discovery and polygenic prediction from a genome-wide association study of educational attainment in 1.1 million individuals. Nat Genet 50, 1112-1121 (2018)

53. A. Djaileb, B. Charron, M.H. Jodaylami, V. Thibault, J. Coutu, K. Stevenson, S. Forest, L.S. Live, D. Boudreau, J.N. Pelletier, J.F. Masson, A rapid and quantitative serum test for SARS-CoV-2 antibodies with portable surface plasmon resonance sensing. ChemRxiv 15, 10-26434 (2020)

54. J.H. Lee, M. Choi, Y. Jung, S.K. Lee, C.S. Lee, J. Kim, J. Kim, N.H. Kim, B.T. Kim, H.G. Kim, A novel rapid detection for SARS-CoV-2 spike 1 antigens using human angiotensin converting enzyme 2 (ACE2). Biosens Bioelectron 171, 112715 (2021)

55. F. Andrade, A. Bianco, G. Reina, S. Peng, L. Jacquemin, Hard nanomaterials in time of viral pandemics. ACS Nano 14, 9364 $9388(2020)$
56. G.B. Melikyan, Common principles and intermediates of viral protein-mediated fusion: the HIV-1 paradigm. Retrovirology 5, $1-13(2008)$

57. Y. Zhou, J. Agudelo, K. Lu, D.H. Goetz, E. Hansell, Y.T. Chen, W.R. Roush, J. McKerrow, C.S. Craik, S.M. Amberg, Inhibitors of SARS-CoV entry-identification using an internally-controlled dual envelope pseudovirion assay. Antivir Res 92, 187-194 (2011)

58. Y. Zhou, P. Vedantham, K. Lu, J. Agudelo, R. Carrion Jr., J.W. Nunneley, D. Barnard, S. Pöhlmann, J.H. McKerrow, A.R. Renslo, Protease inhibitors targeting coronavirus and filovirus entry. Antivir Res 116, 76-84 (2015)

59. BioTek, In vitro assays for antiviral drug development : solutions from BioTek. Agil 8 (2020)

60. E.M. Campbell, T.J. Hope, HIV-1 capsid: the multifaceted key player in HIV-1 infection. Nat Rev Microbiol 13, 471-483 (2015)

61. S. Stauffer, F. Nebioglu, A. Helenius, In vitro disassembly of influenza A virus capsids by gradient centrifugation. J. Vis. Exp. (109), e53909 (2016)

62. E. De Clercq, G. Li, Approved antiviral drugs over the past 50 years. Clin Microbiol Rev 29, 695-747 (2016)

63. Z. Zhang, E. Yang, C. Hu, H. Cheng, C.Y. Chen, D. Huang, R. Wang, Y. Zhao, L. Rong, M. Vignuzzi, Cell-based high-throughput screening assay identifies 2', 2'-difluoro-2'-deoxycytidine gemcitabine as a potential antipoliovirus agent. ACS Infect Dis 3, 45-53 (2017)

64. A. Munjal, R. Khandia, K. Dhama, S. Sachan, K. Karthik, R. Tiwari, Y.S. Malik, D. Kumar, R.K. Singh, H. Iqbal, Advances in developing therapies to combat Zika virus: current knowledge and future perspectives. Front. Microbiol. 8, 1469 (2017)

65. B. Coutard, K. Barral, J. Lichière, B. Selisko, B. Martin, W. Aouadi, M.O. Lombardia, F. Debart, J.-J. Vasseur, J.C. Guillemot, Zika virus methyltransferase: structure and functions for drug design perspectives. J. Virol. 91 (2017)

66. J. Deka, A. Mojumdar, P. Parisse, S. Onesti, L. Casalis, DNAconjugated gold nanoparticles based colorimetric assay to assess helicase activity: a novel route to screen potential helicase inhibitors. Sci. Rep. 7, 44358 (2017)

67. J.-B. Cho, J.-M. Lee, H.-C. Ahn, Y.-J. Jeong, Identification of a novel small molecule inhibitor against SARS coronavirus helicase. J. Microbiol. Biotechnol. 25, 2007-2010 (2015)

68. M. Grønborg, T.Z. Kristiansen, A. Stensballe, J.S. Andersen, O. Ohara, M. Mann, O.N. Jensen, A. Pandey, A mass spectrometrybased proteomic approach for identification of serine/threoninephosphorylated proteins by enrichment with phospho-specific antibodies: identification of a novel protein, Frigg, as a protein kinase A substrate. Mol. Cell. Proteomics 1, 517-527 (2002)

69. J. Sumaoka, H. Akiba, M. Komiyama, Selective sensing of tyrosine phosphorylation in peptides using Terbium (III) complexes. Int. J. Anal. Chem. 2016 (2016)

70. K. Anstett, B. Brenner, T. Mesplede, M.A. Wainberg, HIV drug resistance against strand transfer integrase inhibitors. Retrovirology 14, 36 (2017)

71. A.T. Podany, K.K. Scarsi, C.V. Fletcher, Comparative clinical pharmacokinetics and pharmacodynamics of HIV-1 integrase strand transfer inhibitors. Clin. Pharmacokinet. 56, 25-40 (2017)

72. S.J. Stray, J.M. Johnson, B.G. Kopek, A. Zlotnick, An in vitro fluorescence screen to identify antivirals that disrupt hepatitis B virus capsid assembly. Nat. Biotechnol. 24, 358-362 (2006)

73. R. Hadravová, M. Rumlová, T. Ruml, FAITH-fast assembly inhibitor test for HIV. Virology 486, 78-87 (2015)

74. K. Teruya, Y. Hattori, Y. Shimamoto, K. Kobayashi, A. Sanjoh, A. Nakagawa, E. Yamashita, K. Akaji, Structural basis for the development of SARS 3CL protease inhibitors from a peptide mimic to an aza-decaline scaffold. Pept. Sci. 106, 391-403 (2016)

75. S. Joshi, L. Chen, M.B. Winter, Y.-L. Lin, Y. Yang, M. Shapovalova, P.M. Smith, C. Liu, F. Li, A.M. LeBeau, The 
rational design of therapeutic peptides for aminopeptidase $\mathrm{N}$ using a substrate-based approach. Sci. Rep. 7, 1-11 (2017)

76. M. Rai, S.D. Deshmukh, A.P. Ingle, I.R. Gupta, M. Galdiero, S. Galdiero, Metal nanoparticles: the protective nanoshield against virus infection. Crit. Rev. Microbiol. 42, 46-56 (2016)

77. A.R. Sofy, A.A. Hmed, N.F. Abd El Haliem, M.A.-E. Zein, R.F.M. Elshaarawy, Polyphosphonium-oligochitosans decorated with nanosilver as new prospective inhibitors for common human enteric viruses. Carbohydr. Polym. 226, 115261 (2019)

78. T.Q. Huy, N.T.H. Thanh, N.T. Thuy, P. Van Chung, P.N. Hung, A.-T. Le, N.T.H. Hanh, Cytotoxicity and antiviral activity of electrochemical-synthesized silver nanoparticles against poliovirus. J. Virol. Methods 241, 52-57 (2017)

79. Y. Li, Z. Lin, T. Xu, C. Wang, M. Zhao, M. Xiao, H. Wang, N. Deng, B. Zhu, Delivery of VP1 siRNA to inhibit the EV71 virus using functionalized silver nanoparticles through ROS-mediated signaling pathways. RSC Adv. 7, 1453-1463 (2017)

80. V.K. Sharma, K.M. Siskova, R. Zboril, J.L. Gardea-Torresdey, Organic-coated silver nanoparticles in biological and environmental conditions: fate, stability and toxicity. Adv. Colloid Interf. Sci. 204, 15-34 (2014)

81. X.C. Yang, C.M. Li, C.Z. Huang, Curcumin modified silver nanoparticles for highly efficient inhibition of respiratory syncytial virus infection. Nanoscale 8, 3040-3048 (2016)

82. Y. Li, Z. Lin, M. Zhao, T. Xu, C. Wang, L. Hua, H. Wang, H. Xia, B. Zhu, Silver nanoparticle based codelivery of oseltamivir to inhibit the activity of the H1N1 influenza virus through ROSmediated signaling pathways. ACS Appl. Mater. Interfaces 8, 24385-24393 (2016)

83. Y. Li, Z. Lin, M. Zhao, M. Guo, T. Xu, C. Wang, H. Xia, B. Zhu, Reversal of H1N1 influenza virus-induced apoptosis by silver nanoparticles functionalized with amantadine. RSC Adv. 6, 89679-89686 (2016)

84. Z. Lin, Y. Li, M. Guo, T. Xu, C. Wang, M. Zhao, H. Wang, T. Chen, B. Zhu, The inhibition of H1N1 influenza virus-induced apoptosis by silver nanoparticles functionalized with zanamivir. RSC Adv. 7, 742-750 (2017)

85. M. El-Gaffary, M.M. Bashandy, A.R. Ahmed, O.M. El-Borady, Self-assembled gold nanoparticles for in-vitro inhibition of bovine viral diarrhea virus as surrogate model for $\mathrm{HCV}$. Mater. Res. Express. 6, 75075 (2019)

86. A.R. Bastian, C.G. Ang, K. Kamanna, F. Shaheen, Y.-H. Huang, K. McFadden, C. Duffy, L.D. Bailey, R.V.K. Sundaram, I. Chaiken, Targeting cell surface HIV-1 Env protein to suppress infectious virus formation. Virus Res. 235, 33-36 (2017)

87. A. Halder, S. Das, D. Ojha, D. Chattopadhyay, A. Mukherjee, Highly monodispersed gold nanoparticles synthesis and inhibition of herpes simplex virus infections. Mater. Sci. Eng. C 89, 413-421 (2018)

88. X. Huang, M. Li, Y. Xu, J. Zhang, X. Meng, X. An, L. Sun, L. Guo, X. Shan, J. Ge, Novel gold nanorod-based HR1 peptide inhibitor for middle east respiratory syndrome coronavirus. ACS Appl. Mater. Interfaces 11, 19799-19807 (2019)

89. J. Kim, M. Yeom, T. Lee, H.-O. Kim, W. Na, A. Kang, J.-W. Lim, G. Park, C. Park, D. Song, Porous gold nanoparticles for attenuating infectivity of influenza A virus. J. Nanobiotechnol. 18, 1-11 (2020)

90. C.E. Peña-González, P. García-Broncano, M.F. Ottaviani, M. Cangiotti, A. Fattori, M. Hierro-Oliva, M.L. González-Martín, J. Pérez-Serrano, R. Gómez, M.Á. Muñoz-Fernández, Dendronized anionic gold nanoparticles: synthesis, characterization, and antiviral activity. Chem. Eur. J. 22, 2987-2999 (2016)

91. M. Sametband, S. Shukla, T. Meningher, S. Hirsh, E. Mendelson, R. Sarid, A. Gedanken, M. Mandelboim, Effective multi-strain inhibition of influenza virus by anionic gold nanoparticles. Med. Chem. Commun. 2, 421-423 (2011)
92. M. Horie, H. Ogawa, Y. Yoshida, K. Yamada, A. Hara, K. Ozawa, S. Matsuda, C. Mizota, M. Tani, Y. Yamamoto, Inactivation and morphological changes of avian influenza virus by copper ions. Arch. Virol. 153, 1467 (2008)

93. Y. Fujimori, T. Sato, T. Hayata, T. Nagao, M. Nakayama, T. Nakayama, R. Sugamata, K. Suzuki, Novel antiviral characteristics of nanosized copper (I) iodide particles showing inactivation activity against 2009 pandemic H1N1 influenza virus. Appl. Environ. Microbiol. 78, 951-955 (2012)

94. N. Shionoiri, T. Sato, Y. Fujimori, T. Nakayama, M. Nemoto, T. Matsunaga, T. Tanaka, Investigation of the antiviral properties of copper iodide nanoparticles against feline calicivirus. J. Biosci. Bioeng. 113, 580-586 (2012)

95. A. Tavakoli, M.S. Hashemzadeh, Inhibition of herpes simplex virus type 1 by copper oxide nanoparticles. J. Virol. Methods 275, 113688 (2020)

96. T.E. Antoine, Y.K. Mishra, J. Trigilio, V. Tiwari, R. Adelung, D. Shukla, Prophylactic, therapeutic and neutralizing effects of zinc oxide tetrapod structures against herpes simplex virus type- 2 infection. Antivir. Res. 96, 363-375 (2012)

97. S. Goodarzi, T. Da Ros, J. Conde, F. Sefat, M. Mozafari, Fullerene: biomedical engineers get to revisit an old friend. Mater. Today 20, 460-480 (2017)

98. A. Muñoz, B.M. Illescas, J. Luczkowiak, F. Lasala, R. RibeiroViana, J. Rojo, R. Delgado, N. Martín, Antiviral activity of selfassembled glycodendro [60] fullerene monoadducts. J. Mater. Chem. B 5, 6566-6571 (2017)

99. J. Ramos-Soriano, J.J. Reina, B.M. Illescas, N. de la Cruz, L. Rodríguez-Pérez, F. Lasala, J. Rojo, R. Delgado, N. Martín, Synthesis of highly efficient multivalent disaccharide/[60] fullerene nanoballs for emergent viruses. J. Am. Chem. Soc. 141, 15403-15412 (2019)

100. M.Z. Fahmi, W. Sukmayani, S.Q. Khairunisa, A.M. Witaningrum, D.W. Indriati, M.Q.Y. Matondang, J.-Y. Chang, T. Kotaki, M. Kameoka, Design of boronic acid-attributed carbon dots on inhibits HIV-1 entry. RSC Adv. 6, 92996-93002 (2016)

101. S. Huang, J. Gu, J. Ye, B. Fang, S. Wan, C. Wang, U. Ashraf, Q. Li, X. Wang, L. Shao, Benzoxazine monomer derived carbon dots as a broad-spectrum agent to block viral infectivity. J. Colloid Interface Sci. 542, 198-206 (2019)

102. T. Tong, H. Hu, J. Zhou, S. Deng, X. Zhang, W. Tang, L. Fang, S. Xiao, J. Liang, Glycyrrhizic-acid-based carbon dots with high antiviral activity by multisite inhibition mechanisms. Small 16, $1906206(2020)$

103. A.R. Deokar, A.P. Nagvenkar, I. Kalt, L. Shani, Y. Yeshurun, A. Gedanken, R. Sarid, Graphene-based "hot plate" for the capture and destruction of the herpes simplex virus type 1. Bioconjug. Chem. 28, 1115-1122 (2017)

104. X. Du, R. Xiao, H. Fu, Z. Yuan, W. Zhang, L. Yin, C. He, C. Li, J. Zhou, G. Liu, Hypericin-loaded graphene oxide protects ducks against a novel duck reovirus. Mater. Sci. Eng. C 105, 110052 (2019)

105. I.S. Donskyi, W. Azab, J.L. Cuellar-Camacho, G. Guday, A Lippitz, W.E.S. Unger, K. Osterrieder, M. Adeli, R. Haag, Functionalized nanographene sheets with high antiviral activity through synergistic electrostatic and hydrophobic interactions. Nanoscale 11, 15804-15809 (2019)

106. M. Sametband, I. Kalt, A. Gedanken, R. Sarid, Herpes simplex virus type- 1 attachment inhibition by functionalized graphene oxide. ACS Appl. Mater. Interfaces 6, 1228-1235 (2014)

107. Z. Lin, Y. Li, G. Gong, Y. Xia, C. Wang, Y. Chen, L. Hua, J. Zhong, Y. Tang, X. Liu, Restriction of H1N1 influenza virus infection by selenium nanoparticles loaded with ribavirin via resisting caspase-3 apoptotic pathway. Int. J. Nanomedicine 13, 5787 (2018) 
108. Y. Li, Z. Lin, M. Guo, M. Zhao, Y. Xia, C. Wang, T. Xu, B. Zhu, Inhibition of H1N1 influenza virus-induced apoptosis by functionalized selenium nanoparticles with amantadine through ROS-mediated AKT signaling pathways. Int. J. Nanomedicine 13, 2005 (2018)

109. Y. Li, Z. Lin, M. Guo, Y. Xia, M. Zhao, C. Wang, T. Xu, T. Chen, B. Zhu, Inhibitory activity of selenium nanoparticles functionalized with oseltamivir on H1N1 influenza virus. Int. J. Nanomedicine 12, 5733 (2017)

110. Z. Lin, Y. Li, M. Guo, M. Xiao, C. Wang, M. Zhao, T. Xu, Y. Xia, B. Zhu, Inhibition of H1N1 influenza virus by selenium nanoparticles loaded with zanamivir through p38 and JNK signaling pathways. RSC Adv. 7, 35290-35296 (2017)

111. L. Delgado-Roche, F. Mesta, Oxidative stress as key player in severe acute respiratory syndrome coronavirus (SARS-CoV) infection. Arch. Med. Res. (2020)

112. S. Ramya, T. Shanmugasundaram, R. Balagurunathan, Biomedical potential of actinobacterially synthesized selenium nanoparticles with special reference to anti-biofilm, anti-oxidant, wound healing, cytotoxic and anti-viral activities. J. Trace Elem. Med. Biol. 32, 30-39 (2015)

113. T.E. Antoine, S.R. Hadigal, A.M. Yakoub, Y.K. Mishra, P. Bhattacharya, C. Haddad, T. Valyi-Nagy, R. Adelung, B.S.
Prabhakar, D. Shukla, Intravaginal zinc oxide tetrapod nanoparticles as novel immunoprotective agents against genital herpes. J. Immunol. 196, 4566-4575 (2016)

114. A. Agelidis, L. Koujah, R. Suryawanshi, T. Yadavalli, Y.K. Mishra, R. Adelung, D. Shukla, An intra-vaginal zinc oxide tetrapod nanoparticles (zoten) and genital herpesvirus cocktail can provide a novel platform for live virus vaccine. Front. Immunol. 10, 500 (2019)

115. C. Zilker, D. Kozlova, V. Sokolova, H. Yan, M. Epple, K. Überla, V. Temchura, Nanoparticle-based B-cell targeting vaccines: tailoring of humoral immune responses by functionalization with different TLR-ligands. Nanomed. Nanotechnol. Biol. Med. 13, 173182 (2017)

116. M. Kopp, U.W. Aufderhorst, M. Alt, U. Dittmer, A.-M. EisHübinger, B. Giebel, M. Roggendorf, M. Epple, A. Krawczyk, Induction of herpes simplex virus type 1 cell-to-cell spread inhibiting antibodies by a calcium phosphate nanoparticle-based vaccine. Nanomed. Nanotechnol. Biol. Med. 16, 138-148 (2019)

117. M. Rezaei, S.N. Hosseini, R.A. Khavari-Nejad, F. Najafi, M. Mahdavi, HBs antigen and mannose loading on the surface of iron oxide nanoparticles in order to immuno-targeting: fabrication, characterization, cellular and humoral immunoassay. Artif. Cells Nanomed. Biotechnol. 47, 1543-1558 (2019) 